IZA DP No. 5604

The Aggregate Effects of Trade and Migration: Evidence from OECD Countries

Francesc Ortega

Giovanni Peri

March 2011 


\title{
The Aggregate Effects of Trade and Migration: Evidence from OECD Countries
}

\author{
Francesc Ortega \\ Queens College CUNY \\ and IZA \\ Giovanni Peri \\ University of California, Davis \\ and NBER
}

\section{Discussion Paper No. 5604 \\ March 2011}

IZA

P.O. Box 7240

53072 Bonn

Germany

Phone: +49-228-3894-0

Fax: +49-228-3894-180

E-mail: iza@iza.org

\begin{abstract}
Any opinions expressed here are those of the author(s) and not those of IZA. Research published in this series may include views on policy, but the institute itself takes no institutional policy positions.

The Institute for the Study of Labor (IZA) in Bonn is a local and virtual international research center and a place of communication between science, politics and business. IZA is an independent nonprofit organization supported by Deutsche Post Foundation. The center is associated with the University of Bonn and offers a stimulating research environment through its international network, workshops and conferences, data service, project support, research visits and doctoral program. IZA engages in (i) original and internationally competitive research in all fields of labor economics, (ii) development of policy concepts, and (iii) dissemination of research results and concepts to the interested public.
\end{abstract}

IZA Discussion Papers often represent preliminary work and are circulated to encourage discussion. Citation of such a paper should account for its provisional character. A revised version may be available directly from the author. 


\section{ABSTRACT \\ The Aggregate Effects of Trade and Migration: Evidence from OECD Countries}

Two large but separate bodies of literature analyze the economic effects of international trade and immigration. Given that several factors are important determinants of both trade and migration flows, the previous studies are vulnerable to a potentially serious omitted-variables bias, questioning the validity of existing estimates of the effects of trade and immigration on income. This paper provides estimates of the effects of trade and immigration on income in a unified framework. We also provide a useful decomposition of the channels at work in terms of the employment rate, the capital intensity, and total factor productivity of the receiving economy. We assemble panel data on immigration flows, output, employment and capital stocks for thirty OECD countries over the period 1980-2007. In order to identify the causal effects of trade and immigration on economic outcomes we adopt and extend the gravitybased approach in Frankel and Romer (1999). Our predictors for trade and immigration flows are based on geography and the demographic trends of each country's trade and migration partners. We find that immigration has a large, positive effect on the employment rate of the receiving country. However, it leaves income per capita unaffected because of an offsetting negative effect on TFP. In contrast, trade flows appear to increase income per capita, mainly through TFP growth, and have no impact on the employment rate. The positive employment effect of immigration is the most robust of all the effects identified in this paper.

JEL Classification: F22, E25, J61

Keywords: international migration, trade, income, geography

Corresponding author:

Francesc Ortega

Queens College CUNY

Economics Department

300A Powdermaker Hall

65-30 Kissena Blvd

Flushing, New York 11367

USA

E-mail: fortega@qc.cuny.edu

\footnotetext{
* We are grateful to Seema Sangita for her extremely valuable help with the data and to Paul Gaggl for very useful suggestions.
} 


\section{Introduction}

Economists believe that an important part of the economic success of countries is driven by their openness to ideas, investment, capital and labor from the rest of the world. Open economies enjoy the benefits from new ideas and goods, greater competition and access to skills and talents beyond those already within their borders. All these forces can potentially fuel economic growth. However, exposure to competition from the rest of the world may also have negative effects on subsets of the population. Globalization of trade flows is often blamed for the off-shoring of manufacturing jobs, employment losses in previously protected industries, and downward pressure on the wages of low-skill workers in rich countries. Likewise greater openness to immigration is often seen as a threat to the labor market outcomes of domestic workers.

The literature on the economic effects of globalization has evolved along separate branches regarding the effects of greater openness to trade and migration flows. The trade literature has focused on quantifying the gains from trade and its channels. To mention but a few, Coe and Helpman (1995) examined the role of international trade as a vehicle of knowledge diffusion. Feenstra and Hanson (1999) investigated the effects of trade on wages. Frankel and Romer (1999) and Alcalá and Ciccone (2004) analyzed the effects of trade openness on economic growth and aggregate productivity. In comparison, the immigration literature has concentrated mainly on the labor-market effects, with an emphasis on the outcomes of low-skill native workers (e.g. Card, 2001; Borjas, 2003, and many others.). Only a few papers have considered openness to trade and migration within the same framework. Specifically, Borjas, Freeman, Katz, DiNardo, and Abowd (1997) used the factor proportions model to evaluate the joint effect of trade and migration on factor prices. More recently, Ottaviano, Peri, and Wright (2010) have analyzed the employment effect of hiring immigrants and off-shoring jobs on native employment in the context of many productive tasks.

This paper seeks to contribute to the literature on the aggregate economic effects of openness by extending the empirical framework in Frankel and Romer (1999) by including openness to immigration in addition to trade openness. Considering these two dimensions of openness jointly is potentially crucial for the analysis as migration and trade are very highly correlated and often driven by the same determinants. Yet, immigration and trade policies in most countries are rather different from each other. Empirical studies that only consider one dimension of openness are thus vulnerable to a potentially serious omitted variable bias. Moreover trade flows are increasingly associated and tied with off-shoring and re-importing of intermediate goods (hence with capital movements) and migration, especially those of highly educated, are associated with transfers of knowledge and human capital. Hence these two flows capture most of the relevant circulation of ideas and technology that has been unleashed in the era of globalization. From a policy point of view, it is crucial to know whether the employment and productivity effects of openness are mainly driven by immigration or by trade since the policy implications are vastly different. This paper aims at separately identifying the economic effects of these two 
dimensions of openness.

Our analysis also decomposes the overall effect of openness on output into several components: labor intensity (measured by employment rate), capital intensity (measured by capital per worker), and technology and production efficiency (measured by total factor productivity). This decomposition is useful because it allows us to evaluate the relevance of different channels through which economies adjust to increases in economic openness. As discussed earlier, there are multiple channels through which trade flows can affect income. This is also the case for immigration, as highlighted by the large number of recent contributions to this question. For instance, immigration may affect aggregate income through its effects on native workers' employment and wages (as in Borjas, 2003; Ottaviano and Peri, 2011; Ottaviano, Peri, and Wright, 2010; Chassamboulli and Palivos, 2010). It may also alter the receiving economy's industrial and occupational composition (e.g. Cortés and Tessada, 2010; Farré, González, and Ortega, 2009; Frattini, 2010; Peri and Sparber, 2009) the relative capital-labor intensities and production technologies at the industry or at the firm level (Lewis, 2005; González and Ortega, 2011; Dustmann and Glitz, 2010). While there is some evidence that all these channels are at work, their relative importance has not yet been explored. Our results are helpful in this respect because some of these mechanisms will induce changes in labor intensity, while others will mostly operate through changes in capital intensity or total factor productivity.

Obviously, economic development is a cause as well as a consequence, of immigration and trade. Hence, uncovering the causal effects of openness to international trade and migration is not a trivial task. Building on Frankel and Romer (1999), we exploit the fact that countries differ in their geographic location and in the demographic trends of their trade partners and migrant-sending countries. This allows us to construct predictions for openness to trade and migration that can be considered exogenous to country-specific unobserved determinants of income growth. Our predictors are based solely on the demographic trends of partner countries and on geography. As long as these variables are not directly causing economic growth in the destination countries our exclusion restriction will be satisfied. Furthermore we also argue that our instrumental-variables strategy allows us to separately identify the causal effects of trade and immigration.

This paper also contributes to the literature by providing a new migration dataset with a larger coverage in terms of years and countries than used in previous studies. We assemble annual data on bilateral trade and migration flows into thirty OECD countries originating from all countries in the world for the period 1980-2007. Our bilateral migration data is the result of merging several sources (United Nations, OECD Migration database and Mayda 2010), imputing some missing values, and homogenizing definitions. We have also conducted numerous consistency checks. The bilateral trade data are taken from the IFS Direction of Trade Statistics (2007) revision and include trade between the OECD countries and 190 partners in each year (with some missing in the years before 1989) beginning in 1980. Our dataset also contains income per person, 
employment, population and capital stocks for all OECD countries for 1980-2007. These data allow for a joint analysis of the effects of trade and migration on income both in the short run (annual) and in the medium run (four-year periods) on a sample of countries that accounts for a very large share of world trade and migration over our period of interest. We also note that by restricting our analysis to OECD destination countries we reduce the likelihood that differences in the quality of institutions or other unobserved factors may operate as confounding factors.

Our analysis is closely related to Frankel and Romer (1999) but differs from it in several important aspects. As noted already, our main specifications feature both trade openness and immigration rates as regressors. Second, we exploit both the cross-sectional and longitudinal variation of the data, which allows us to estimate specifications that account for all time-invariant determinants of income. ${ }^{1}$ Third, we explicitly consider the effect of globalization on employment-population ratios, capital intensity and TFP. The first is particularly important since in the presence of labor market rigidities it may well be the case that globalization has important effects on employment (rather than output per worker) in the short and medium run.

Our analysis delivers three main results. First, our instrumental-variables estimates confirm the findings in Frankel and Romer (1999) in the specifications that feature trade openness only as a regressor (that is, omitting immigration). Namely, trade openness has a positive and significant effect on income per capita, already in the short run, arising mainly from a large positive effect on the employment rate. Second, when we consider the analogous specification for immigration (that is, omitting trade openness) we obtain very similar results. Immigration is associated with a short-run increase in income per capita driven mostly by an increase in the employment rate. However, when we include both trade openness and immigration (whose bilateral flows are highly correlated) as regressors the pattern of estimates changes significantly, indicating an important omitted variable bias in the previous estimates.

Our instrumental-variables estimates of the econometric models accounting jointly for trade and immigration suggest that trade still has a positive effect on income per capita. However, this effect is smaller than before and it operates mainly through a positive and significant effect on TFP growth. In comparison, immigration has no effect on income per capita in the short run. Moreover the decomposition reveals that immigration has a large, positive effect on the economy's employment rate that is offset by a negative effect on TFP. There appears to be no significant changes to capital intensity, suggesting that immigration triggers a capital inflow that helps prevent capital dilution even in the short run. This pattern of results is robust to restricting our analysis to a subsample for which we have higher quality data or a more balanced bilateral panel and to accounting for re-migration and out-migration. Moreover, when we consider long time-differences the previous findings are qualitatively confirmed.

\footnotetext{
${ }^{1}$ Specifically, our dependent variables are log changes. Hence, time-invariant factors have been differenced out.
} 
The magnitude of the effects described above, using our preferred basic specification, is the following. A one percentage point increase in trade openness increases income per capita by 0.6 to $0.9 \%$. An immigration flow equal to one percent of the population increases the economy's employment rate by approximately one percent. Specifically, a gross inflow of immigrants equal to $1 \%$ of the population leads to a $1.5 \%$ increase in total employment and to a $0.5 \%$ increase in population ${ }^{2}$. As a result, the employment-population ratio increases by about $1 \%$. A possible interpretation of these findings, discussed further in the conclusions, is as follows. Trade openness stimulates economic growth by inducing a relocation of factors across industries and firms leading to gains in production efficiency (as in Melitz 2003). At the aggregate level this is reflected in TFP growth. On the other hand immigration stimulates employment growth by providing skills complementary to those of natives (e.g. Ottaviano and Peri, 2011), and pushing firms to create more jobs in immigration intensive sectors. Firms can cut costs on those jobs by paying immigrants less than their marginal productivity (e.g. Chassamboulli and Palivos, 2010; Ottaviano, Peri, and Wright, 2010). This generates employment opportunities for native workers, with some downward pressure on productivity per worker.

The rest of the paper is organized as follows. Section 2 describes the framework and the empirical specifications that we use to analyze the impact of immigration and openness to trade on economic outcomes. Section 3 describes the data and the construction of the instruments. Section 4 presents the main estimates. Section 5 presents our robustness checks and section 6 concludes.

\section{Empirical Framework}

Our simple framework can be described with just a few equations. It is an extension of Frankel and Romer (1999). We generically represent an economic outcome for country $i$ in year $t$ with $x_{i t}$. In what follows, $x_{i t}$ alternatively stands for income per person $y_{i t}$ or one of its components, such as its employment-population ratio $e_{i t}$, its capital-labor ratio $k_{i t}$, or its total factor productivity $A_{i t}$. In the fashion of the cross-country economic growth literature, we assume a production function that combines capital and labor in a Cobb-Douglas fashion, with an elasticity of output to capital equal to $\alpha$. In this case the four outcomes described above are related as follows:

$$
y_{i t}=A_{i t} k_{i t}^{\alpha} e_{i t}
$$

Employment-population ratio $e_{i t}$ summarizes the labor intensity, capital per worker $k_{i t}$ is the (relative) intensity in the use of capital, and total factor productivity $A_{i t}$ is a measure of the quality-efficiency of capital and labor. It is plausible to expect that each of these variables will be affected by the general degree of openness

\footnotetext{
${ }^{2}$ As several people re-migrate it is reasonable to expect that the growth in population is smaller than the inflow of immigrants.
} 
of the economy through the frequency of interactions with foreign economic agents and the resulting exchange of ideas, skills, factors of production, and more intense product-market competition. Building on Frankel and Romer (1999), we assume that a country's economic outcomes are a log-linear function of its cumulated exposure to international trade. Continued exposure to international trade spreads knowledge, stimulates competition and selects more productive firms. It is, however, important to control for the size of the country. Large countries are more diversified in terms of ideas, skills, and factors of production, which increases the frequency of productive interactions taking place within their borders. We also postulate that the frequency and quality of these economic interactions can also depend on the country's cumulated openness to immigration. ${ }^{3}$ More formally,

$$
\ln x_{i t}=\alpha_{x t}^{\prime}+\beta_{x} T_{i t}+\gamma_{x} M_{i t}+\delta_{x} S_{i}+\varepsilon_{i t}^{\prime}
$$

As noted earlier, $x_{i t}$, the economic outcome of interest for country $i$ in year $t$, depends on $T_{i t}$, a measure of the accumulated openness to foreign goods (for instance, the stock of imported capital or ideas relative to the total stock), $M_{i t}$ is a measure of the accumulated openness to foreign individuals (such as the stock of immigrants as share of the population), and $S_{i}$ captures the size of the country. The term $\alpha_{x t}^{\prime}$ captures the other systematic determinants of the outcome variables and $\varepsilon_{i t}^{\prime}$ is a mean-zero random variable accounting for random shocks to $\ln x_{i t}$. In time-differences, expression (2) becomes

$$
\Delta \ln x_{i t}=\alpha_{x t}+\beta_{x} \tau_{i t}+\gamma_{x} m_{i t}+\varepsilon_{i t}
$$

where $\tau_{i t}$ and $m_{i t}$ are flow measures of openness to international trade and international migration, respectively. We proxy these flow measures using exports plus imports as a share of GDP (for $\tau_{i t}$ ) and the flow of new immigrants relative to the population of the country at the beginning of the year (for $m_{i t}$ ). Let us note that these measures of openness to trade and to immigration are relative to the scale of the country (in terms of output or population) because they proxy for exposure to foreign goods and foreign individuals. Note also that the time-invariant measure of country size has been differenced out. Obviously, disturbance $\varepsilon_{i t}$ has a zero mean as it is the difference between $\varepsilon_{i t}^{\prime}$ and $\varepsilon_{i t-1}^{\prime}$.

The main empirical challenge in the estimation of (3) is the potential endogeneity of the exposure to both foreign goods and foreign people, as shocks to economic activity may affect both. Countries that receive positive shocks to income per capita may increase their international trade flows and may also attract more immigrants. To isolate the causal effect of openness to foreign goods and people on a country's economic outcomes we use the fact that openness is also a function of two kinds of external factors: the country's geographic location and the size of its potential (trade and migration) partners. We assume that these factors are uncorrelated

\footnotetext{
${ }^{3}$ Consider, for instance, the sustained increase in migration flows within EU countries since the Schengen treaty was adopted.
} 
with unobserved determinants of economic growth in our country of interest, as given by equation (3). More specifically, the time-invariant geographic variables include bilateral distance, common border, colonial ties and common language. The potential partner characteristics we consider are purely demographic (population size and the share of young individuals in the population) and vary over time.

We estimate auxiliary regressions that predict bilateral trade and migration flows using demographic information for the potential partner countries, and bilateral geographic (and cultural) variables. These regressions are closely related to the highly successful gravity equations in the international trade and migration literature (and both recently micro-founded by Anderson and van Wincoop (2003) and Grogger and Hanson (2008)). However, our predictors differ from the standard gravity regressions in one fundamental point. In our bilateral regressions we omit all information regarding the destination country. For instance, we predict the trade (migration) flows between country $i$ and its trading partner $j$ using only the (plausibly exogenous) interactions of the time-invariant bilateral characteristics and the time-varying demographics of country $j$. Thus, if country $i$ is located near large countries in terms of population it will be predicted to have a high degree of trade (migration) openness. $^{4}$

More specifically, we assume that trade openness of country $i$ towards country $j$ is described by:

$$
\begin{aligned}
\ln \tau_{i j t}= & a^{\tau}+b_{1}^{\tau} \ln P_{j t}+b_{2}^{\tau} B_{i j}+b_{3}^{\tau} B_{i j}\left(\ln P_{j t}\right)+b_{4}^{\tau} \ln (d i s t)_{i j}+ \\
& b_{5}^{\tau} C_{i j}+b_{6}^{\tau} L_{i j}+e_{t}^{\tau} .
\end{aligned}
$$

The dependent variable is the sum of the bilateral trade between the two countries (exports from $i$ to $j$ plus exports from $j$ to $i$ ) relative to the destination country's GDP. In the right-hand side, $a^{\tau}$ is an intercept, $P_{j t}$ is the population in country of origin $j$ in year $t, B_{i j}$ is an indicator for common border, dist ${ }_{i j}$ is bilateral distance, $C_{i j}$ is an indicator for colonial ties, $L_{i j}$ is an indicator for common language, and $e_{t}^{\tau}$ is a zero-mean error term.

Similarly we express the openness to migration of country $i$ vis-a-vis $j$ by

$$
\begin{aligned}
\ln m_{i j t}= & a^{m}+b_{1}^{m} \ln P_{j t}+b_{2}^{m} B_{i j}+b_{3}^{m} B_{i j}\left(\ln P_{j t}\right)+b_{4}^{m} \ln (d i s t)_{i j}+ \\
& b_{5}^{m} C_{i j}+b_{6}^{m} L_{i j}+b_{7}^{m} \ln s_{j t}+e_{t}^{m} .
\end{aligned}
$$

The dependent variable is the log of the bilateral (gross) migration flow from country $j$ to country $i$, divided by the destination country's population. ${ }^{5}$ All the right-hand side variables in equation (4) are also included

\footnotetext{
${ }^{4}$ In comparison Frankel and Romer (1999) include also the population of the destination country as an explanatory variable for bilateral trade flows.

${ }^{5}$ A fully symmetric definition of openness to migration would also include the migration flows from $i$ to $j$. However, these data are not available for many origin countries. More importantly, for the case of migration it seems clear that inflows are a more important determinant of a country's economic outcomes than outflows and most of the considered OECD countries have a net positive immigration.
} 
here. But, in addition, we include $s_{j t}$, the share of young people in origin country $j$ in year $t$. The presence of large cohorts of young individuals in the potential countries of origin is considered as a relevant determinant of migration $^{6}$. Auxiliary regressions (4) and (5) are used to predict bilateral trade and immigration flows. However equation (3) calls for destination-country-specific predictions of openness to trade and migration. Accordingly, we aggregate our bilateral predictions over origin countries: $\widehat{\tau_{i t}}=\sum_{j} \exp \left(\ln \widehat{\tau_{i j t}}\right)$ and $\widehat{m_{i t}}=\sum_{j} \exp \left(\ln \widehat{m_{i j t}}\right)$.

Our key identifying assumption is that the explanatory variables included in equations (4) and (5) are uncorrelated with the error term in equation (3). This assumption would be violated by the existence of unobserved factors that simultaneously affect demographics in the origin countries and short-run changes to economic outcomes at destination.

Given that the explanatory variables of our predictors for trade and migration openness are almost identical, separately identifying the roles of the two variables will depend crucially on obtaining meaningful differences between the estimates of vectors $\mathbf{b}^{m}=\left(b_{1}^{m}, b_{2}^{m}, \ldots, b_{7}^{m}\right)$ and $\mathbf{b}^{\tau}=\left(b_{1}^{\tau}, b_{2}^{\tau}, \ldots, b_{6}^{\tau}\right)$. To strengthen identification we have also included the age structure of the population (share of the population with age 15-29) only in the migration predictor. This choice is based on a large body of literature documenting the high propensity to migrate for young individuals (Hatton and Williamson, 1998; Hanson and McIntosh, 2010). In contrast, this demographic group is likely to be relatively unimportant in terms of production and trade since a substantial share may be enrolled in school and their workplace experience is still relatively limited.

\section{Bilateral Trade and Migration flows}

\subsection{Data}

To estimate regressions (4) and (5) we use data on bilateral trade and migration flows between all (origin) countries in the world (with available data) and the 30 OECD (destination) countries. Table A1 in the appendix lists the countries covered by our data. It also reports the number of immigration sending countries for which there is non-zero migration for each destination in some representative years. The data are an unbalanced panel beginning in year 1980 and ending in 2007. For a subset of destination countries (14) we have bilateral migration data for the whole period, relative at least to the main countries of origin. Four more countries (France, Luxembourg, UK and Switzerland) have data beginning in the early 1980's (hence no observation in 1980 but several non-zero observations starting in 1983 or 1984). To the contrary, the other countries have a shorter span of coverage for their data. For the shorter period 1998-2007 we have data for many more countries. However, some individual bilateral flows are missing for some years (for instance bilateral data in

\footnotetext{
${ }^{6}$ Pritchett (2006) argues that non-EU immigration will continue to rise in the European Union as a result of the diverging demographic futures of Europe and the countries in the north of Africa. Several of these countries have large and growing populations and a large share of young population and, in the light of recent events in Egypt, highly unsatisfied with economic prospects in their countries.
} 
some destinations are only collected within a subperiod) and some countries do not report all the bilateral flows each year (hence, a smaller number of sending countries is reported in some years). Some countries are particularly limited in terms of identifying immigrants by country of origin. The worst cases are Ireland, which only explicitly identifies migrants from the UK and the USA, and Greece, for which the OECD database contains migration flows exclusively in the year 1998. In general, however, receiving countries tend to consistently report data from all the main sending countries, hence the increase in numbers of zero-observations in some years is often due to the non-recording of countries with an extremely low number of observations.

Our immigration data measure the yearly inflow of foreign citizens who intend to be residents (at least for some time) in the receiving countries. To span the whole period of analysis, still with some limitations and differences across countries, we have merged bilateral immigration data from three sources. The first source is Ortega and Peri (2009). The OECD original series were discontinued in 1994 and with the help of Mayda (2010) we extended the series up to 2005. The second source is United Nations (2005), which reports very long time series but only for a subset of 15 destination countries. This source goes back to the sixties for some countries, but ends in the early 2000's for all of them. The third source is the International Migration database (IMD) gathered by the OECD and available up to $2007 .{ }^{7}$ The latter has the most extensive coverage in terms of destination and sending countries, but it only begins in 1998, and for some destinations it only has few countries as source. We have made sure that the definitions of immigrant are consistent across databases for each receiving country. Essentially, all datasets use as primary sources the original data released by the statistical offices of each receiving country, which try to maintain internal consistency over time. In our checks we often find an exact coincidence of the figures in overlapping periods. Occasionally there are slight differences introducing discontinuities as we merge two series from different sources. In those cases we include a dummy in the regression to account for the possible discrete jump, as we describe below. Table A2 in the Appendix summarizes the availability from each data source by destination country. Specifically, starting with the UN migration data, we have filled in missing origin-destination-year observations from the IMD data. Next, we have used the data in Ortega and Peri (2009) where IMD and UN data were missing. In a limited number of cases we have also interpolated observations. We did this only when a data point for a bilateral migration flow was missing and both the previous and following years were available.

The total inflow of immigrants each year for each country of destination constitutes what we call total (gross) immigration. We also constructed a measure of total net immigration for each receiving country, where we correct for the outflow of foreign persons, due to re-migration or return migration. These data have partial coverage as they are only available in the IMD data. We use them to perform sensitivity analysis.

The bilateral trade data in current US dollars are from the IMF, Direction of Trade Statistics (DOT), October

\footnotetext{
${ }^{7}$ Downloadable at http://stats.oecd.org/Index.aspx? DataSetCode=MIG.
} 
2007 release $^{8}$. This database is a substantial improvement on the previous DOT release (used in Frankel and Romer (1999)). It covers 190 countries (many more than it did earlier) and it has a very accurate coverage of import and export flows especially for the period 1998-2007. No other database on trade data has coverage extending to the recent years and covering as many countries (e.g. the UN-NBER trade data collected by ?? ${ }^{9}$ ends in 2000, the WTO world trade statistics does not collect data for such a fine breakdown of partners). The measure of openness to trade for each destination country is the sum of imports and exports relative to GDP and is obtained from the Penn World Tables, version 6.2. The demographic data for the origin countries (total population and share of the population age 15-29) are from the Penn World Tables version 6.2 and from the UN Population Statistics. The data on income and employment are from OECD datasets and cover the whole period 1980-2007. Specifically, GDP and capital stock data are from the OECD Productivity dataset, and employment data are from the OECD-STAN dataset.

We also make use of the data on aggregate investment in the Penn World Tables (version 6.2) to increase the coverage of the capital stock data. Using these data we compute total factor productivity as a Solow residual, assuming a CRS Cobb-Douglas production function with a labor share of 0.66 and using total employment and capital stock as the inputs into production. ${ }^{10}$

Table 1 reports some summary statistics for the sample of destination countries: immigration rates, trade openness, and log changes for GDP per person, total GDP, population, employment, capital, and TFP. The upper panel covers the whole period and the lower panel is restricted to the sub-period (1998-2007) for which we have immigration data for a larger number of destination countries. Several observations are worth noting. First, there is a large difference in our measures of the degree of openness to trade and openness to foreign migrants. Traded goods account on average for $76 \%$ of output. Assuming roughly equal imports and exports, about one third of the value of the goods consumed in a country originate from abroad. In contrast, new immigrants are on average only $0.62 \%$ of the receiving country's population. In order to obtain regression coefficients that have roughly the same magnitude we use immigration rates in percentages and openness to trade in shares in our analysis (the standard deviation of both is around 0.5). Second, immigration rates, while small, are of the same magnitude as population growth rates $(0.62 \%$ and $0.51 \%$, respectively). Hence, in our sample immigration on average accounted for a large share of the total population growth in the receiving countries. Income per person grew on average by $2.2 \%$ per year, with TFP growth accounting for about half of the increase. Increases in the employment-population ratio and capital deepening contributed in similar magnitudes to the remaining economic growth over this period.

\footnotetext{
${ }^{8}$ Described at http://www2.imfstatistics.org/DOT/help/DOThelp.htm.

${ }^{9}$ And available at http://cid.econ.ucdavis.edu/data/undata/undata.html.

${ }^{10}$ Ideally, it would be cleaner to use total hours worked and capital services (as opposed to capital stocks) to build our TFP measure. However, these data are only available for a small subset of our data. At any rate, our less sophisticated measure of TFP is highly consistent with the series reported in the OECD Productivity dataset. In a regression of growth rates of the two TFP measures we find that the estimated coefficient is 0.92 and the standard error is 0.018 .
} 


\subsection{Auxiliary Regressions}

As described in section 2, we use gravity equations (4) and (5) to build predictions of immigration rates and trade openness by destination country that are based on geography and origin-country demographic data.

In our regressions we drop missing observations (usually in the early years of the sample) and we add one unit to the zero trade or zero immigrants observations within the sample and include them in the auxiliary regressions. This way, as we run regressions in logarithms, we do not loose the information contained in the zeroes. We estimate regressions (4) and (5) by OLS. We point out that we do not include any time or fixed effect in order to make use of variation in trade openness and bilateral migration rates that arises purely from bilateral geographic variables (together with common language and colonial ties dummies) and partner-country demographics. We then calculate, for each destination and year, the overall predicted immigration rate and trade openness as $\widehat{\tau_{i t}}=\sum_{j} \exp \left(\ln \widehat{\tau_{i j t}}\right)$ and $\widehat{m_{i t}}=\sum_{j} \exp \left(\ln \widehat{m_{i j t}}\right)$.

Table 2 reports the OLS estimates of (4) and (5). Columns 1 and 2 display results for the bilateral immigration rate. The specification in column 1 is identical to the one used to predict bilateral trade openness in column 3. Column 2 includes the share of young in the sending countries in the prediction of immigration rates. The estimated coefficients are generally in line with those estimated in the literature. Our estimates in column 3 are comparable to those in Frankel and Romer (1999) and Frankel and Rose (2002). ${ }^{11}$ A few points are worth noting. First, both for immigration and trade flows, bilateral distance and the size of the origin country in terms of population are statistically and economically important. However, both variables have a stronger effect on the flows of goods than on the flows of persons. In contrast, common language plays a much larger role in determining migration than trade, consistent with language being key in facilitating skill transferability, and a more rapid economic and cultural assimilation of migrants. Likewise, the presence of a large and young country near the border (e.g. Mexico and the US) is a more important predictor of bilateral migration than of trade flows. Finally, colonial ties appear to affect trade more than migration. Traditionally many free trade agreements followed the lines of previous colonial empires.

The estimated coefficients in columns 1 and 3 imply substantial differences in the weights assigned to the regressors in our predictions of trade openness and immigration rates. Additionally, to strengthen identification of their separate roles, our main predictor for immigration rates (column 2) also includes the share of young (age 15 to 29) in the countries of origin, but we do not include it to explain trade openness. As emphasized in the immigration literature (Hatton and Williamson, 1998; Hanson and McIntosh, 2010; Clark, Hatton, and Williamson, 2007), this share of the population displays higher migration rates and there is no evidence indicating that the role of this young cohort in production (of internationally traded goods) is particularly large. ${ }^{12}$ As

\footnotetext{
${ }^{11}$ Frankel and Rose (2002) estimate a similar specification for bilateral trade flows on a cross-section of data for year 1990 . They find a coefficient of 0.82 for the log of the origin population, -1.43 for log distance, and 0.53 for the common language dummy (not included in Frankel and Romer (1999)). These estimates are also replicated in Cavallo and Frankel (2008).

${ }^{12}$ In fact its coefficient was not significant when entered in the trade regression.
} 
expected, the share of young is highly significant (column 2) and increases the goodness of fit of the bilateral migration regression by about $10 \%$.

While one can add a whole set of additional variables and interactions in the gravity equations, our goal is to identify a minimal set of geographic factors and origin-country demographic factors that is likely to be uncorrelated with unobserved determinants of income growth in the destination country. Additional explanatory variables, such as measures of economic size and performance of the partner countries, while surely increasing the goodness of fit of our predictors, would reduce the credibility of the exclusion restriction. Our identifying assumption is based on the idea that the location of a country, its language and colonial ties, and the demographic structure of its potential partner countries are not correlated with annual changes in income per person, employment-population ratio, capital intensity and total factor productivity of the country, except through bilateral trade and migration flows. While some large scale economic shocks (natural catastrophes, large recessions, financial crisis) can affect the economies of many countries simultaneously, unless they also affect the demography and the geography of the countries of origin they will not affect the validity of our instrument. ${ }^{13}$

\subsection{Relevance of the instruments}

Table 3 reports the results of a series of regressions aimed at examining the explanatory power of our predicted immigration rates and degree of trade openness. All these regressions are at the level of destination-country and year. The dependent variable in columns 1 and 2 is the immigration rate by destination. While in column 1 the main explanatory variable is the predicted immigration rate, column 2 also includes the predicted trade flows as a fraction of GDP. Columns 3 and 4 are analogous but for the degree of trade openness in the destination country as dependent variable.

Let us start by examining the top panel. Our predictors are highly relevant. As seen in columns 1 and 2 , a predicted immigration rate equal to one percent of the receiving-country's population is associated with an actual immigration rate of 0.35 to $0.36 \%$ and the percentage of variance explained is over $50 \%$. Analogously, our predicted trade flows are highly relevant in explaining actual trade openness, with a coefficient ranging between 1.2 and 1.4 in columns 3 and 4 . In this case, the explained variance rises over $75 \%$. In all cases we can strongly reject the null hypothesis of weak instruments, as evidenced by the high $\mathrm{F}$ statistics on the joint significance of the instruments. Importantly, both immigration rates and trade openness are essentially explained by their respective predictions. Adding predicted trade openness does not improve the F statistic for immigration and likewise when adding predicted immigration to the trade openness regression. In words, there

\footnotetext{
${ }^{13}$ Ortega and Peri (2009) included a set of origin-destination and origin-yearfixed effects in their predictors. Obviously, their predictors accounted for a larger share of the variation in actual bilateral and migration flows. However, one should be concerned that these catch-all variables, albeit specific to the countries of origin, may also be absorbing variation that is correlated with economic outcomes at destination. In comparison here we pursue a much more conservative approach by only including variables in our gravity predictors that are very likely to be uncorrelated with shocks to economic conditions in the destination countries.
} 
is a differential impact of geography and origin-country demographics on the flows of goods and migrants. This is a very important pre-requisite to separately identify the causal effects of immigration and trade openness on income growth and its determinants.

The middle panel reports the results of specifications that include destination-country fixed effects. ${ }^{14}$ Our predictors are still significant although standard errors increase substantially. As a result, the strength of the instruments is greatly reduced, particularly for trade openness. In column 3 we cannot reject the null of weak instruments and in column 4 predicted trade flows become non-significant. ${ }^{15}$ This suggests that a large part of the power of our instruments for trade (and to a lesser extent for migration) flows is due to cross-sectional variation. This is reasonable given that geography is time-invariant and the demographics of the countries of origin move only slowly over time. Hence, while the instrument is successful in predicting trade openness variation across countries and years, its within-country performance is much weaker. Let us emphasize again that our specifications are in logarithmic changes and they already account for time-invariant destination-country factors that determine the levels of income per person, employment rates, capital per worker, and TFP. These factors account, to a large extent, for cross-country differences in policies, institutions and initial income levels. Thus our regressions identify the impact of trade flows and migration flows on the changes in economic outcomes.

The bottom panel reports the first-stage regressions for the reduced sample period (1998-2007) for which we have observations for 30 OECD countries. The results are very similar to those in the top panel. It is worth noting in column 2 (bottom panel) that the predictor for immigration and for trade openness have opposite signs. This reinforces our conviction that the instruments are successful in separately identifying the roles of immigration and trade openness on income growth.

\section{The Effects of Immigration and Trade on Income}

We now turn to the central question of this paper. How do trade and immigration flows affect income growth and its components? Our main specification is equation (3) using, alternatively, as dependent variables log changes in income per person, in the employment-population ratio, in capital per worker, and in total factor productivity. The main explanatory variables are the degree of trade openness $\left(\tau_{i t}\right.$, the ratio of exports plus imports relative to GDP) and the immigration rate $\left(m_{i t}\right.$, annual inflows of new immigrants relative to the total initial population). The main sample contains 30 OECD countries and spans (unbalanced) the period 1980-2007 at an annual frequency.

\footnotetext{
${ }^{14}$ We note that the specifications in (3) are already in changes. Hence, unlike Frankel and Romer (1999) we are already accounting for time-invariant determinants of income per person. Likewise, equations (4) and (5) predict flows of goods and people, as opposed to stocks.

${ }^{15}$ Note that the standard errors are roughly ten times larger in the middle panel of column 3 compared to the top panel.
} 


\subsection{OLS estimates}

Table 4 reports the OLS estimates of equation (3). Each column corresponds to a different dependent variable. We consider regression models featuring as main explanatory variable either solely the immigration rate, or solely the degree of trade openness. The latter is comparable to the specification in Frankel and Romer (1999). But we also consider specifications jointly featuring the immigration rate and the degree of trade openness. Since in our data both variables are significantly correlated, the latter specification is preferred as it is less vulnerable to omitted variable bias. ${ }^{16}$

All specifications contain year dummies and a set of indicators accounting for each observation's source of immigration data. The latter account for potential discrete jumps in the immigration data across data sources. Obviously, these OLS estimates are subject to potential endogeneity bias both on account of immigrants' location choices and on the responsiveness of trade flows to unobserved income shocks. Clearly, these concerns are less severe for the estimates reported in panel B (bottom), which also include destination-country fixed effects. These effects absorb all time-invariant determinants of income growth, mitigating to some extent the previous source of bias.

Let us begin by examining the estimates of trade openness on the economic outcomes of interest. As shown in column 1, there is a significant positive association between trade openness and income growth. Moreover, this effect is qualitatively robust to including the immigration rate as a regressor and to including destinationcountry fixed effects. Note though that in the latter case (panel B) the standard errors increase by a factor of five. Interestingly, the point estimate in our specification where trade openness is the only regressor (panel A, middle set of estimates) is very similar to that obtained by Frankel and Romer (1999) in a comparable specification, at 0.93 and 0.85 , respectively. In addition, the estimates in columns 2 through 4 reveal positive associations between trade openness and growth in employment rates and TFP, while a negative association with growth in capital intensity. We defer interpreting the pattern of estimates and discussing the magnitudes of the effects until the next section.

Let us now turn to the role of immigration rates for income growth and its determinants. As seen in panel A (column 1), the immigration rate appears to be uncorrelated with the short-run growth of GDP per person. This is true both in the regression model featuring immigration solely and in the one containing trade openness as well, with and without destination-country fixed effects. That is, the lack of association between immigration and short-run income growth is a robust feature of the data. Interestingly, the results in columns 2 across all specifications reveal a robust positive association between immigration rates and log changes in the employment rate. Specifically, an inflow of immigrants equal to $1 \%$ of the population is associated to an increase in the

\footnotetext{
${ }^{16}$ The correlation coefficient between immigration rates and trade openness across country-year observations is 0.49 . When we estimate a regression model for trade openness using as regressors the immigration rate, year dummies and country dummies, the point estimate on the immigration rate is 0.13 , with a robust standard error of 0.03 .
} 
employment rate of $0.37 \%$ (joint specification with fixed effects). The large increase in the employment rate reflects a large effect on total employment, together with a smaller effect on the total population. ${ }^{17}$ Turning to column 3, there appears to be a non-zero association between immigration and changes in capital intensity. However, while in panel A the point estimate is negative in both cases, in panel B it is positive. As discussed earlier, the specification including destination-country fixed effects is more reliable since it requires weaker, though still restrictive, assumptions for consistent estimates. Based on the estimates in column 5, we do not find any significant association between immigration rates and TFP growth. Of course, all of these need not be causal effects. It is entirely possible that immigrants choose to move to countries where income, employment rates, capital intensities and TFP are growing for unobserved reasons. In this case, we would expect the estimates reported in Table 4 to be upwardly biased. The instrumental-variables estimates in the next section will address this issue.

\subsection{Two-stage least-squares estimates}

The biggest limitation of the OLS estimates in Table 4 is that they are subject to endogeneity bias, arising both from immigration and trade openness potentially being affected by unobserved determinants of income growth. To address these issues we adopt an instrumental-variables approach, in which we use our gravity-based predictions for immigration and trade openness as instruments.

Table 5 reports the results of the 2SLS estimation. Panel A (top) reports estimates for specifications containing year dummies and immigration-data-source dummies. The specifications in panel B (bottom) additionally include destination-continent fixed effects. ${ }^{18}$ This set of dummy variables absorbs unobserved determinants of income growth that remain constant over time during our sample period, such as international treaties facilitating trade and migration among neighboring countries. As before, our most preferred specifications are the ones that jointly include the immigration rate and trade openness as explanatory variables.

Let us begin by examining the estimates of the regression models that include either the immigration rate or trade openness in the right-hand side (the top two regressions in panel A). First of all, we note that the coefficient on trade openness is 0.73 , statistically different from zero. The preferred 2SLS estimate in Frankel and Romer (1999) is 1.99, with an associated standard error of approximately 1. Noguer and Siscart (2005) estimate a specification identical to Frankel and Romer (1999) but using better data. ${ }^{19}$ Their preferred estimate is around 1 (with a standard error ranging between 0.28 and 0.45 ), which is very close to our point estimate.

\footnotetext{
${ }^{17}$ When we estimated the impact of immigration rate on employment and population separately (not shown but available upon request) we found a coefficient around 0.5 for population and around 1 for employment.

${ }^{18} \mathrm{As}$ discussed earlier, when destination-country fixed effects are introduced our instruments are weakened substantially. As a second-best option we follow Frankel and Romer (1999) and include a less demanding set of destination-continent fixed effects.

${ }^{19}$ Noguer and Siscart (2005) use bilateral trade data from the World Trade Database (1997 release). This data contain 8, 096 bilateral observations. In comparison, Frankel and Romer (1999) use bilateral trade data from the IFS Direction of Trade Statistics, 1997 release, containing only 3,220 observations and relying heavily on imputation. We use the more recent 2007 release of IFS statistics that contains many more observations especially for the period 1998-2007.
} 
Hence, our results are highly consistent with previous studies estimating the effect of trade on income.

Secondly, scrolling across columns it is striking that immigration and trade appear to have very similar effects: they increase income per person and employment rates, yet reducing capital per worker. While this may certainly be the case, it could also be driven by an omitted variable problem arising from a strong positive correlation between openness to trade and to immigration. To address this concern we now turn to our preferred specification, where the right-hand-side features both the immigration rate and trade openness. Interestingly, the qualitative pattern of our estimated effects changes substantially, strongly suggesting an omitted variables problem in regression models that fail to include either openness to trade or openness to immigration.

Regarding the effects of trade openness, we now find only marginally significant positive coefficients (third regression in panel A). When continent fixed-effects are included (panel B) the point estimate increases moderately (from 0.6 to 0.9 ) but so does the standard error so that we can not reject the null of a zero coefficient. Interestingly, this was also the case in Frankel and Romer (1999). When they introduced continent dummies their point estimate was around one and not statistically different from zero. Furthermore, our estimates suggest that trade openness may lead to TFP growth but, at the same time, reduce capital intensity, although these estimates are only marginally significant. Our interpretation is that increases in trade openness for OECD countries may stimulate the reallocation of labor towards more knowledge-intensive sectors, raising the efficiency and overall factor productivity of the economy as a whole. We notice a further interesting result relative to Frankel and Romer (1999). In that paper they always estimated larger coefficients of openness on income when using 2SLS methods relative to OLS methods. This runs counter to the intuition of circular causality between trade and openness, that should be addressed by the instruments, producing, therefore, a smaller point estimate. The authors were well aware of that and they spent section II.E addressing and discussing this issue. One of the possible explanations is that the instrument is correlated with other variables affecting income, other than trade. Hence geography affects income through those and generate a classic omitted variable bias, that may be exacerbated by the instruments if they are particularly correlated with the omitted variable. Immigration could be such a variable. In our case, including both variables in the estimation the OLS and 2SLS method produce coefficients of similar magnitude, in fact usually the effect of openness on income per person is smaller in the 2SLS case than in the OLS (see Table 4 Panel B versus Table 5 Panel A and B).

Let us now turn to the effects of immigration. The estimates in panel A (third regression) and panel B suggest that it has no effect on income per person in the short run (column 1). In contrast, immigration has a large, positive effect on the employment rate of the receiving economy, without significantly affecting capital intensity. Finally, immigration is associated to a negative effect on TFP. More specifically, our estimates suggest that an immigration inflow equal to one-percent of the population in the receiving country leads to a 
one percent increase in the employment rate and to an equally-sized reduction in TFP. ${ }^{20}$ These estimates of the short-run effects of immigration suggest that immigration triggers a capital inflow that keeps the capital-labor ratio essentially unchanged. Regarding the large effect on the employment rate, we note that it is not driven by a composition effect but by an increase in the employment rates of natives. ${ }^{21}$. Before providing an interpretation in the conclusions section, let us now examine the robustness of these findings.

\section{Extensions}

\subsection{Balanced panels}

One concern is that the data are noisier for the earlier years in our sample period, since the quality of the immigration data is somewhat lower for those years. Indeed we had to rely more heavily on imputation and combine more sources of immigration data for that period than for more recent years. Another concern is data are better and more consistent for some countries (those with a longer history of immigration and more developed) than others. On one hand an important robustness check is to repeat the analysis using only the period 1998-2007, for which we have a panel covering the 30 OECD countries and our bilateral migration data is from a single data source (the OECD International Migration Data). On the other, the larger sample of countries implies that for some of them the bilateral migration data are not very complete (some countries only report few sending countries and possibly only some years). Hence, we will also construct a panel of fewer countries (the 14 for which we have uninterrupted data 1980-2007 plus France, Great Britain, Switzerland and Luxembourg whose data begin in the early eighties) but with an almost balanced and full time series in each.

Table 6 reports OLS and 2SLS estimates for the period 1998-2007, with and without continent dummies. The results strongly confirm our previous findings. In particular, the point estimates we obtain are very similar to those reported in Table 5 for our most preferred specification, the one including both immigration and trade openness as regressors and continent dummies (panel C). Immigration has no short-run effects on income per person. That is to say, it increases GDP in the short run by the same percentage amount as it increases the population. Moreover, immigration has a large positive effect on the employment rate, which is offset by a negative TFP effect of the same magnitude, and no capital dilution. The pattern for the effects of trade is also the same as in Table 5: trade openness has a marginally positive effect on income per capita (column 1, panels $\mathrm{B}$ and C). ${ }^{22}$ This effect is the combination of a negative effect on capital intensity but an offsetting positive

\footnotetext{
${ }^{20}$ When destination-country fixed effects are included (not shown but available upon request) the standard errors grow by one order of magnitude. As a result the point estimates become virtually uninformative. We remind the reader that our main specifications are in log-changes and, therefore, time-invariant determinants of income per person will not affect the consistency of our 2SLS estimation.

${ }^{21}$ As shown repeatedly in the literature, the employment rates of natives and immigrants (with the same age and schooling) are roughly similar (see for instance Docquier, Ozden, and Peri (2010))

${ }^{22}$ In additional regressions we have verified that the increase in income per capita arising from trade openness is driven by an increase in total GDP, with no effect on the size of population.
} 
effect on TFP (columns 3 and 4, panels B and C). It is worth noting that the standard errors that we obtain in the smaller sample are comparable, and sometimes smaller, than those in Table 5 for the whole sample. This is partly due to the better quality data and partly by the fact that our shorter but wider panel relies more on cross-sectional variation.

In terms of magnitudes, our estimates imply that an inflow of immigrants equal to $1 \%$ of the population increases the employment-population ratio by $1 \%$ as well (and reduces TFP by roughly the same amount). In comparison, if we take the point estimates at face value, a one percent increase in the trade to GDP ratio raises income per person $0.67 \%$, mainly due to a growth in TFP of $1 \%$.

Table 7 reports OLS and 2SLS estimates for the longer almost balanced panel of 18 countries, 1980-2007, with and without continent dummies. The results are also in line with the previous findings. In particular, focussing on the 2SLS estimates, that are quite consistent with or without continent dummies, we note that immigration has no short-run effects on income per person. That is to say, it increases GDP in the short run by the same percentage amount as it increases the population. Moreover, immigration has a large positive and significant effect on the employment rate. This effect is offset by a negative TFP effect of similar magnitude (but not statistically significant), and no capital dilution. In this longer panel of fewer countries the employment impact of immigration seems even larger. The pattern for the effects of trade is similar to that in Table 5 but the statistical significance is lost in this specification. Trade openness has a positive non significant effect on income per capita (column 1, panels B and C). This effect is the combination of a negative non significant effect on capital intensity and employment rate and an offsetting positive (and non significant) effect on TFP (columns 3 and 4, panels $\mathrm{B}$ and $\mathrm{C}$ ). The longer panel, relative to countries that are main destinations of immigrants and have a longer time series, shows that the estimated short-run effects of trade are rather fragile while the positive effect of immigrants on employment rate and the zero effect of immigration on income per capita are robust and confirmed.

\subsection{Net immigration}

A criticism that applies to our previous estimates and to many aggregate studies attempting to estimate the effects of immigration on income is that they use gross inflows as a proxy for net inflows. This is a data limitation arising from the fact that, in most countries, foreigners settling in the country have an obligation to register their arrival. However, those leaving the country often do not have the obligation and simply do not report their departure. As a result, the governments of the immigration countries lack accurate data on immigrant outflows. Only data obtained from detailed censuses of residents and not those compiled annually by population registries, can measure net immigration.

Exceptionally, a few studies have used special data to report high re-migration (return) rates of immigrants 
in the UK (Dustmann and Weiss, 2007) and in the US (Lalonde and Topel, 1993) but it remains hard to obtain comprehensive data for a large number of countries. The IMD data produced by the OECD partially addresses this issue since it contains data both on gross inflows and outflows for the period 1998-2007 by country of origin. These estimates are based on cancellations of immigrants from local registers and from estimates of the change in the stock of immigrants between two points in time. Using these data we construct the yearly net immigration rates (inflow minus outflow of foreign individuals by country of origin). While still affected by the tendency to under-register of the departing migrants, these data go at least part way in allowing us to construct the ideal variable that should be used to estimate the effects of immigration on economic outcomes of the receiving country.

Table 8 reports OLS and 2SLS estimates of our models using our measure of net immigration (relative to population). We report the estimates only for our most preferred specification featuring both immigration and trade openness as regressors and continent dummies. Three points are worth emphasizing. First, the net immigration rates are also predicted rather well by the gravity instrument. ${ }^{23}$ Second, the pattern of the 2 SLS estimates on the effects of immigration is largely consistent with our previous findings (columns 1 and 2 , panels B and C). Immigration has no effect on income per person in the short run. It increases the employment rate but it reduces TFP by a similar amount. The results on trade openness are roughly similar to our main findings. They are however less precisely estimated.

\subsection{Longer time intervals}

So far our results represent short-run effects, in the sense that our dependent variables were annual log changes. One may have several concerns regarding this relatively high frequency. First, it may take some time until the effects of immigration on economic outcomes become measurable. Moreover, there may be a complicated pattern of auto-correlation in the error terms. In order to address these concerns we re-estimate our models using longer differences and, more specifically, 4-year periods.

Table 9 reports the estimates of the models with long differences. The top panel reports OLS estimates and the middle and bottom panels report 2SLS estimates, with and without continent dummies. Again, the main pattern observed earlier regarding the effects of immigration survives this robustness check. Immigration does not affect income per person in the longer run, indicating that the increase in total income is similar to the increase in total population. Moreover, the employment rate increases with approximately a unit elasticity and TFP falls by a similar magnitude. Our estimates for the effects of trade openness are less precise than in our main set of estimates. Standard errors here are about ten times larger than in Table 5. ${ }^{24}$ Even though the

\footnotetext{
${ }^{23}$ The F statistic associated to the first-stage regression is above 70 in all specifications and each coefficient is individually highly significant.

${ }^{24}$ Interestingly, the standard errors for the estimates of the effects of immigration are less than twice as large as in the annual models. This is a relatively modest increase given the large reduction in the number of observations.
} 
signs of the point estimates are the same as those in Table 5 we cannot reject the null hypothesis of zero effects of trade openness in any of the columns in panel C. More precisely the emerging pattern is that of very large positive effects of trade on productivity and income per person but very imprecise estimates.

\subsection{Limitations of the instrumental-variables strategy}

We next discuss two limitations of our approach. First, we wish to examine to what extent our results depend on the specific set of destination countries (OECD) included in our analysis. We note that these countries are relatively homogeneous in a number of dimensions, implying an important challenge for our pseudo-gravity predictors for immigration and trade flows arising from the limited cross-sectional variation in geography and demographics of the origin countries. To evaluate these issues we have conducted our analysis omitting a number of countries and we have found that omitting Luxembourg, a country with large actual and predicted trade flows and immigration rates weakens the results by significantly reducing the predictive power of our instruments, both in the case of immigration and trade openness. Table A3 in the appendix shows that while the OLS results still exhibit a significant effect of immigration on the employment rate and of trade openness on income per person. However, in our 2SLS estimates those effects are no longer significant (they maintain however the sign of those in table 5). This sensitivity of the gravity-based instruments to the omission of Luxembourg from the sample was also noted by Frankel and Romer (1999, page 385, footnote 12) who argued in favor of keeping Luxembourg in the sample in order to take advantage of the identification power deriving from it.

A second interesting issue is whether the employment and productivity effects of immigration and trade depend on the fact that a large part of those flows are with other OECD countries. In this respect we conduct our analysis using only the bilateral trade and migration flows between OECD destinations and non-OECD origins. Table A4 in the appendix reports the resulting estimates. Clearly, standard errors are much larger now than for our main set of estimates (Table 5). The reason is that a large part of the strength of our instrument comes from the predicted (trade and immigration) flows among OECD countries. ${ }^{25}$ At any rate, the 2SLS estimates still reveal no significant effects of immigration rates on income per person and a positive effect on the employment rate that is offset by a negative effect on TFP. Likewise, we find a marginally significant positive effect of trade openness on GDP per person. However the estimates of trade effects become too unstable to be taken seriously. In conclusion, it is mainly OECD-OECD trade flows and that play a large role in delivering a strong set of instruments. ${ }^{26}$. However the direction of the effects of trade and migration is similar, with migration stimulating employment rates and trade stimulating TFP growth.

\footnotetext{
${ }^{25}$ Recall that a large share of international trade flows is intra-industry trade among similarly developed countries.

${ }^{26}$ The F statistics associated to the first-stage regressions in this restricted sample are substantially lower than in the main sample. Specifically, it is 33 for the predicted immigration rate and below 9 for the predicted trade openness.
} 


\section{Discussion and Conclusions}

This paper asks a central question in international economics: how do international flows of people and goods affect economic performance? There are many competing theories that address these questions, differing in their emphasis on the roles of factor differences, technology, product variety, and so on. All these theories have predictions regarding the effects of international trade and migration on income per person and its determinants. Nevertheless, there are practically no cross-country studies providing joint estimates of the effects of trade and migration on income per person and, more specifically, on employment rates, capital intensity and total factor productivity. One reason for this has been the lack of adequate international migration data.

Since the pioneering work of Frankel and Romer (1999), several authors have empirically analyzed the effect of international trade on income per person Rodriguez and Rodrik (2001); Frankel and Rose (2002); Cavallo and Frankel (2008); Noguer and Siscart (2005). They have mostly focused on the long run and on level effects. Moreover, by ignoring the role of international migration flows, those studies suffer an important limitation. Many of the determinants of trade flows, particularly relative geography, are also well known to determine migration flows. As a result, it is hard to know whether the existing estimates of the effects of international trade on income in those studies are the result of a spurious correlation mediated by migration flows.

Using a larger dataset and more demanding econometric specifications, our instrumental-variables estimates confirm that trade openness increases income per capita, but possibly with a moderately smaller effect than in previous studies, particularly when estimated in 2SLS and in the short run. Moreover while the point estimate of this effect is positive the standard error is also large, as it was found by Frankel and Romer (1999). Furthermore our results suggest that this positive effect operates through increases in TFP. In turn, our instrumental-variables estimates show that immigration has a large short-run effect on the employment rate of the receiving economy, but no effect on income per capita. This positive effect of immigration on the employment rate is the most robust one throughout the study, being positive and significant in almost each specification. Immigration appears to induce negative TFP growth in the short run that balances the positive employment rate effect and leaves income per worker unchanged.

Our findings suggest that immigration expands the receiving economy along "the extensive margin" not only by adding workers (the immigrants) but also by increasing the employment rate of natives. An interpretation in line with the recent immigration literature is that this effect operates by expanding some sectors (Card and Lewis, 2007; Cortés and Tessada, 2010; Farré, González, and Ortega, 2009), by providing complementary skills (Peri and Sparber, 2009), and by stimulating job creation at the firm level (Chassamboulli and Palivos, 2010). These forces generate higher labor demand for native workers with skills complementary to the newly arrived immigrant workers. In part, the increased demand for labor may arise from cost-cutting by firms, as immigrants are paid less than their marginal products (as in Dustmann, Frattini, and Preston, 2008; Ottaviano, Peri, and 
Wright, 2010; Chassamboulli and Palivos, 2010) and not from productivity enhancements. As a result, the main effect of immigration would appear in the form of employment gains. In comparison, trade expands the economy along the "intensive margin," by increasing the efficiency of use of factors, either eliminating inefficient firms (Melitz, 2003), or reallocating resources to more productive sectors. This does not generate extra employment but raises TFP.

Another difference between the effects of immigration and trade may be that immigration has a disproportionately large effect on non-tradable services, often characterized by being very labor-intensive and with low productivity growth, such as restaurants, household services, child and elderly care, and so on. As immigration expands the size of these low-TFP sectors, it may mechanically reduce the economy's overall TFP through a composition effect, while still generating a positive employment effect on the native labor force as in Cortés and Tessada (2010) and Farré, González, and Ortega (2009). In contrast, international trade flows may have a larger effect on tradable sectors such as manufacturing, which are characterized by high productivity growth.

On the basis of our findings we conclude that the aggregate short-run effects of trade and immigration on income and income per person appear to be neutral or positive. This suggests that a country that is both open to trade and to international migration could benefit from higher employment rates (stimulated by immigrants) as well as higher income per person (stimulated by trade). A combination of sensible policies aimed at enhancing international trade and migration flows may be an important ingredient in delivering employment and income growth. These findings are at odds with the widespread opposition to globalization because of its negative effects on employment. We note though that our analysis has focused on aggregate economic effects, leaving aside distributional concerns that may go a long way in explaining attitudes toward globalization. 


\section{References}

Alcalá, F., and A. Ciccone (2004): "Trade and Productivity," The Quarterly Journal of Economics, 119(2), $612-645$.

Anderson, J. E., And E. van Wincoop (2003): "Gravity with Gravitas: A Solution to the Border Puzzle," American Economic Review, 93(1), 170-192.

BorJas, G. J. (2003): "The Labor Demand Curve Is Downward Sloping: Reexamining The Impact Of Immigration On The Labor Market," The Quarterly Journal of Economics, 118(4), 1335-1374.

Borjas, G. J., R. B. Freeman, L. F. Katz, J. Dinardo, and J. M. Abowd (1997): "How Much Do Immigration and Trade Affect Labor Market Outcomes?," Brookings Papers on Economic Activity, 1997(1), pp. 1-90.

CARD, D. (2001): "Immigrant Inflows, Native Outflows, and the Local Labor Market Impacts of Higher Immigration," Journal of Labor Economics, 19(1), 22-64.

Card, D., and E. G. Lewis (2007): "The Diffusion of Mexican Immigrants During the 1990s: Explanations and Impacts," in Mexican Immigration to the United States, NBER Chapters, pp. 193-228. National Bureau of Economic Research, Inc.

Cavallo, E. A., and J. A. Frankel (2008): "Does openness to trade make countries more vulnerable to sudden stops, or less? Using gravity to establish causality," Journal of International Money and Finance, $27(8), 1430-1452$.

Chassamboulli, A., and T. Palivos (2010): “Give me your Tired, your Poor," so I can Prosper: Immigration in Search Equilibrium," University of Cyprus Working Papers in Economics 12-2010, University of Cyprus Department of Economics.

Clark, X., T. J. Hatton, and J. G. Williamson (2007): "Explaining U.S. Immigration, 1971-1998," The Review of Economics and Statistics, 89(2), 359-373.

Coe, D. T., and E. Helpman (1995): "International R\&D spillovers," European Economic Review, 39(5), 859-887.

Cortés, P., and J. Tessada (2010): "Low-Skilled Immigration and the Labor Supply of Highly Educated Women," Manuscript, Carnegie Mellon University.

Docquier, F., C. Ozden, and G. Peri (2010): "The Wage Effects of Immigration and Emigration," NBer Working Papers 16646, National Bureau of Economic Research, Inc. 
Dustmann, C., T. Frattini, and I. Preston (2008): "The Effect of Immigration along the Distribution of Wages," CReAM Discussion Paper Series 0803, Centre for Research and Analysis of Migration (CReAM), Department of Economics, University College London.

Dustmann, C., And A. Glitz (2010): "How Do Industries and Firms Respond to Changes in Local Labour Supply?," Manuscript, ULC and UPF.

Dustmann, C., And Y. Weiss (2007): "Return Migration: Theory and Empirical Evidence from the UK," British Journal of Industrial Relations, 45(2), 236-256.

Farré, L., L. González, and F. Ortega (2009): "Immigration, Family Responsibilities and the Labor Supply of Skilled Native Women," CReAM Discussion Paper Series 0916, Centre for Research and Analysis of Migration (CReAM), Department of Economics, University College London.

Feenstra, R. C., and G. H. Hanson (1999): "The Impact Of Outsourcing And High-Technology Capital On Wages: Estimates For The United States, 1979-1990," The Quarterly Journal of Economics, 114(3), 907-940.

Frankel, J., and A. Rose (2002): "An Estimate Of The Effect Of Common Currencies On Trade And Income," The Quarterly Journal of Economics, 117(2), 437-466.

Frankel, J. A., And D. Romer (1999): "Does Trade Cause Growth?," American Economic Review, 89(3), 379-399.

Frattini, T. (2010): "Immigration and Prices in the UK," Manuscript, University of Milano.

GonzÁlez, L., and F. Ortega (2011): "How Do Very Open Economies Absorb Large Immigration Flows? Evidence from Spanish Regions," Labour Economics, 18, 57-70.

Grogger, J., And G. H. HAnson (2008): "Income Maximization and the Selection and Sorting of International Migrants," NBER Working Papers 13821, National Bureau of Economic Research, Inc.

Hanson, G. H., and C. McIntosh (2010): "Birth Rates and Border Crossings: Latin American Migration to the US, Canada, Spain, and the UK," NBER Working Papers 16471, National Bureau of Economic Research, Inc.

Hatton, T. J., and J. G. Williamson (1998): The Age of Mass Migration: Causes and Economic Impact. Oxford University Press, New York, NY.

Lalonde, R. J., and R. H. Topel (1993): "Economic impact of international migration and the economic performance of migrants," in Handbook of Population and Family Economics, ed. by M. R. Rosenzweig, and O. Stark, vol. 1 of Handbook of Population and Family Economics, chap. 14, pp. 799-850. Elsevier. 
LEWIS, E. (2005): "Immigration, skill mix, and the choice of technique," Working Papers 05-8, Federal Reserve Bank of Philadelphia.

MAYDA, A. (2010): "International migration: a panel data analysis of the determinants of bilateral flows," Journal of Population Economics, 23(4), 1249-1274.

Melitz, M. J. (2003): "The Impact of Trade on Intra-Industry Reallocations and Aggregate Industry Productivity," Econometrica, 71(6), 1695-1725.

Noguer, M., and M. Siscart (2005): "Trade raises income: a precise and robust result," Journal of International Economics, 65(2), 447-460.

Ortega, F., and G. Peri (2009): "The Causes and Effects of International Migrations: Evidence from OECD Countries 1980-2005," NBER Working Papers 14833, National Bureau of Economic Research, Inc.

Ottaviano, G. I., And G. Peri (2011): "Rethinking the Effects of Immigration on Wages," Journal of the European Economic Association, forthcoming.

Ottaviano, G. I., G. Peri, and G. C. Wright (2010): "Immigration, Offshoring and American Jobs," Working Paper 16439, National Bureau of Economic Research.

Peri, G., And C. Sparber (2009): "Task Specialization, Immigration, and Wages," American Economic Journal: Applied Economics, 1(3), 135-69.

Rodriguez, F., and D. Rodrik (2001): “Trade Policy and Economic Growth: A Skeptic's Guide to the Cross-National Evidence," in NBER Macroeconomics Annual 2000, Volume 15, NBER Chapters, pp. 261338. National Bureau of Economic Research, Inc.

United Nations (2005): "Internationtal Migration Flows ot and From Selected Countries," Rivision 2005, Population Division, the Department of Economic and Social Affairs, Washington, D.C. 


\section{Tables and Figures}

Table 1: Descriptive statistics

\begin{tabular}{|c|c|c|c|c|c|}
\hline Period 1980-2007 & Obs. & Mean & Std. Dev. & Min & $\operatorname{Max}$ \\
\hline Immigration rate $* 100$ & 527 & 0.62 & 0.54 & 0.01 & 3.28 \\
\hline Trade/GDP & 611 & 0.76 & 0.48 & 0.16 & 3.13 \\
\hline$\Delta \ln ($ GDP per Person $) * 100$ & 729 & 2.22 & 3.30 & -23.51 & 11.00 \\
\hline$\Delta \ln ($ Total GDP) $* 100$ & 729 & 2.68 & 3.33 & -23.44 & 11.99 \\
\hline$\Delta \ln$ Population $* 100$ & 581 & 0.51 & 0.46 & -0.59 & 2.08 \\
\hline$\Delta \ln$ Employment $* 100$ & 729 & 0.92 & 1.58 & -7.98 & 20.03 \\
\hline$\Delta \ln ($ Physical Capital) $* 100$ & 692 & 2.95 & 2.17 & -1.45 & 18.18 \\
\hline$\Delta \ln \mathrm{TFP} * 100$ & 692 & 1.13 & 2.73 & -16.38 & 9.17 \\
\hline Period 1998-2007 & & Mean & Std. Dev. & Min & Max \\
\hline Immigration rate* 100 & 268 & 0.68 & 0.62 & 0.01 & 3.28 \\
\hline Trade/GDP & 285 & 0.89 & 0.52 & 0.19 & 3.13 \\
\hline$\Delta \ln ($ GDP per Person $) * 100$ & 280 & 2.83 & 2.36 & -13.52 & 10.50 \\
\hline$\Delta \ln ($ Total GDP $) * 100$ & 280 & 3.22 & 2.35 & -12.78 & 11.22 \\
\hline$\Delta \ln$ Population $* 100$ & 274 & 0.45 & 0.47 & -0.59 & 1.64 \\
\hline$\Delta \ln$ Employment $* 100$ & 280 & 0.97 & 1.18 & -2.50 & 5.75 \\
\hline$\Delta \ln ($ Physical Capital) $* 100$ & 260 & 3.28 & 1.39 & 0.74 & 8.73 \\
\hline$\Delta \ln \mathrm{TFP} * 100$ & 260 & 1.34 & 1.99 & -14.58 & 9.17 \\
\hline
\end{tabular}

Note: Country-year observations covering 30 OECD countries. The mean and standard deviations are unweighted and calculated across countries and years. The immigration rate is defined as the gross inflow of new immigrants over the total population in the country at the beginning of the year. 
Table 2: Gravity regressions for bilateral migration flows and trade flows

\begin{tabular}{|c|c|c|c|}
\hline & [1] & [2] & [3] \\
\hline & Ln Immig. rate & Ln Immig. rate & Ln Trade/GDP \\
\hline \multirow[t]{2}{*}{ ln population origin } & $0.58 * *$ & $0.58 * *$ & $0.91 * *$ \\
\hline & {$[0.04]$} & {$[0.04]$} & {$[0.02]$} \\
\hline \multirow[t]{2}{*}{ Common border } & -1.27 & -2.31 & 0.09 \\
\hline & {$[1.60]$} & {$[1.60]$} & {$[1.42]$} \\
\hline \multirow{3}{*}{$\begin{array}{l}\ln (\text { pop origin } \\
\text { *common border) }\end{array}$} & & & \\
\hline & 0.23 & $0.30 * *$ & 0.10 \\
\hline & {$[0.15]$} & {$[0.13]$} & {$[0.13]$} \\
\hline \multirow[t]{2}{*}{ ln distance } & $-0.60 * *$ & $-0.64 * *$ & $-1.43 * *$ \\
\hline & 0.15 & 0.16 & {$[0.07]$} \\
\hline \multirow[t]{2}{*}{ Colonial ties } & -0.04 & 0.04 & $0.77 * *$ \\
\hline & {$[0.40]$} & {$[0.40]$} & {$[0.30]$} \\
\hline \multirow[t]{2}{*}{ Common language } & $1.64 * *$ & $1.55^{* *}$ & 0.24 \\
\hline & {$[0.31]$} & {$[0.31]$} & {$[0.33]$} \\
\hline \multirow[t]{2}{*}{ Share young origin } & & $0.06 * *$ & \\
\hline & & {$[0.02]$} & \\
\hline Observations & 79,282 & 66,410 & 69,315 \\
\hline R-squared & 0.20 & 0.23 & 0.46 \\
\hline
\end{tabular}

Note: Observations are defined by origin-destination country pairs by year. The immigration rate is defined as new immigrants over total population at the beginning of the year. In Regressions 1 and 2 the dependent variable is the natural logarithm of immigrants from country $\mathrm{j}$ to country i divided by the population of country $\mathrm{i}$. In regression 3 it is the sum of export and imports between countries $i$ and $j$ divided by the GDP of country i. Share of young is the fraction of the population with age 15-29 years old. Standard errors are heteroskedasticity-robust and clustered by destination country. Method of estimation is OLS. $* * * \mathrm{p}<0.01,{ }^{* *} \mathrm{p}<0.05,{ }^{*} \mathrm{p}<0.1$ 
Table 3: First-stage regressions. Power of the gravity-predicted variables

\begin{tabular}{|c|c|c|c|c|}
\hline \multirow{2}{*}{$\begin{array}{l}\text { Panel A: Main } \\
\text { specifications }\end{array}$} & (1) & (2) & (3) & (4) \\
\hline & Imm. rate & Imm. rate & Trade/GDP & Trade/GDP \\
\hline \multirow[t]{2}{*}{ Predicted Imm. rate } & $0.365 * * *$ & $0.355^{* * *}$ & & $0.0938 * * *$ \\
\hline & {$[0.0141]$} & {$[0.0252]$} & & {$[0.0135]$} \\
\hline \multirow[t]{2}{*}{ Predicted Trade/GDP } & & 0.0528 & $1.453 * * *$ & $1.256^{* * *}$ \\
\hline & & [0.108] & {$[0.0448]$} & {$[0.0527]$} \\
\hline Observations & 546 & 546 & 569 & 546 \\
\hline R-squared & 0.529 & 0.529 & 0.758 & 0.784 \\
\hline F statistic & 668 & 334 & 1050 & 989 \\
\hline \multicolumn{5}{|c|}{ Panel B: Destination-country fixed effects } \\
\hline \multirow[t]{2}{*}{ Predicted Imm. rate } & $0.140 * * *$ & $0.131 * * *$ & & $0.0912 * * *$ \\
\hline & {$[0.0217]$} & {$[0.0219]$} & & {$[0.0151]$} \\
\hline \multirow[t]{2}{*}{ Predicted Trade/GDP } & & $1.070 * *$ & $1.169 * * *$ & 0.439 \\
\hline & & {$[0.427]$} & {$[0.426]$} & [0.324] \\
\hline Observations & 546 & 546 & 569 & 546 \\
\hline R-squared & 0.843 & 0.844 & 0.967 & 0.975 \\
\hline F statistic & 41.44 & 26.63 & 7.5 & 22 \\
\hline \multicolumn{5}{|c|}{ Panel C: Main specifications, balanced panel 1998-2007 } \\
\hline \multirow[t]{2}{*}{ Predicted Imm. rate } & $0.385 * * *$ & $0.438 * * *$ & & $0.0930 * * *$ \\
\hline & {$[0.0130]$} & {$[0.0288]$} & & {$[0.0208]$} \\
\hline \multirow[t]{2}{*}{ Predicted Trade/GDP } & & $-0.318 * *$ & $1.644 * * *$ & $1.344 * * *$ \\
\hline & & {$[0.148]$} & {$[0.0705]$} & {$[0.105]$} \\
\hline Observations & 257 & 257 & 265 & 257 \\
\hline R-squared & 0.674 & 0.684 & 0.728 & 0.754 \\
\hline F statistic & 879 & 414 & 545 & 573 \\
\hline
\end{tabular}

Note: The Predicted values for immigration rates and trade/GDP are obtained adding the predictions of specification (2) and (3) of Table 2 across all trading or migration partner countries (j), respectively. The immigration rate is the ratio of new immigrants to the total population at the beginning of the year. Each observation in the regressions is a destination country by year. Standard errors (in square brackets) are heteroskedasticity robust. All regressions include year dummies.

$* * * \mathrm{p}<0.01,{ }^{* *} \mathrm{p}<0.05, * \mathrm{p}<0.1$ 
Table 4: The Effects of Immigration and Trade. OLS Estimates

Panel A: OLS

(2)

(3)

(4)

\begin{tabular}{lcccc} 
& $\Delta \ln (\mathrm{GDP} / \mathrm{Pop})$ & $\Delta \ln (\mathrm{Emp} / \mathrm{POP})$ & $\Delta \ln (\mathrm{K} / \mathrm{Empl})$ & $\Delta \ln \mathrm{TFP}$ \\
\hline Imm. rate & 0.275 & $0.665^{* * *}$ & $-0.780^{* * *}$ & -0.0233 \\
& {$[0.178]$} & {$[0.137]$} & {$[0.143]$} & {$[0.190]$} \\
Observations & 545 & 537 & 536 & 536 \\
R-squared & 0.332 & 0.180 & 0.211 & 0.257 \\
\hline Trade/GDP & $0.937 * * *$ & $0.658^{* * *}$ & $-0.532^{* * *}$ & $0.393 * *$ \\
& {$[0.189]$} & {$[0.0969]$} & {$[0.105]$} & {$[0.188]$} \\
Observations & 582 & 572 & 568 & 568 \\
R-squared & 0.294 & 0.164 & 0.157 & 0.235 \\
\hline Imm. rate & -0.265 & $0.450 * *$ & $-0.595 * * *$ & -0.333 \\
& {$[0.197]$} & {$[0.187]$} & {$[0.205]$} & {$[0.221]$} \\
Trade/GDP & $1.078 * * *$ & $0.428 * * *$ & $-0.359 * *$ & $0.602 * * *$ \\
& {$[0.210]$} & {$[0.152]$} & {$[0.180]$} & {$[0.218]$} \\
Observations & 545 & 537 & 536 & 536 \\
R-squared & 0.365 & 0.194 & 0.218 & 0.268 \\
\hline
\end{tabular}

Panel B: Destination-country fixed effects

\begin{tabular}{lcccc}
\hline Imm. rate & 0.0922 & $0.368 * *$ & $0.631 * * *$ & -0.452 \\
& {$[0.361]$} & {$[0.175]$} & {$[0.229]$} & {$[0.398]$} \\
Trade/GDP & $3.661 * * *$ & $1.187 * *$ & $-1.769 * * *$ & $2.882 * * *$ \\
& {$[0.974]$} & {$[0.502]$} & {$[0.564]$} & {$[1.015]$} \\
Observations & 545 & 537 & 536 & 536 \\
R-squared & 0.489 & 0.273 & 0.427 & 0.349 \\
\hline
\end{tabular}

Note: Units of observations are OECD countries by year. The immigration rate is the ratio of new immigrants to the total population at the beginning of the year. All specifications include year dummies. Regressions including the immigration rate in the right-hand-side also include immigration-data-source dummies. Standard errors (in brackets) are robust to heteroskedasticity.

${ }^{* * *} \mathrm{p}<0.01,{ }^{* *} \mathrm{p}<0.05,{ }^{*} \mathrm{p}<0.1$ 
Table 5: The Effects of Immigration and Trade. 2SLS Estimates.

Panel A: Two-stage least-squares estimates

(1)

(2)

(3)

(4)

\begin{tabular}{lcccc} 
& $\Delta \ln (\mathrm{GDP} / \mathrm{Pop})$ & $\Delta \ln (\mathrm{Emp} / \mathrm{POP})$ & $\Delta \ln (\mathrm{K} / \mathrm{Emp})$ & $\Delta \ln \mathrm{TFP}$ \\
\hline Imm. rate & $0.450^{*}$ & $1.000^{* * *}$ & $-0.779^{* * *}$ & -0.253 \\
& {$[0.250]$} & {$[0.123]$} & {$[0.128]$} & {$[0.246]$} \\
Observations & 537 & 537 & 529 & 529 \\
R-squared & 0.332 & 0.166 & 0.217 & 0.258 \\
\hline Trade/GDP & $0.729^{* * *}$ & $0.571^{* * *}$ & $-0.533^{* * *}$ & 0.329 \\
& {$[0.239]$} & {$[0.136]$} & {$[0.139]$} & {$[0.245]$} \\
Observations & 582 & 572 & 568 & 568 \\
R-squared & 0.292 & 0.163 & 0.157 & 0.235 \\
\hline Imm. rate & -0.102 & $1.033^{* * *}$ & -0.0400 & $-1.047^{* *}$ \\
& {$[0.398]$} & {$[0.270]$} & {$[0.292]$} & {$[0.450]$} \\
Trade/GDP & $0.627^{*}$ & -0.0378 & $-0.829^{* * *}$ & $0.890^{* *}$ \\
& {$[0.360]$} & {$[0.252]$} & {$[0.286]$} & {$[0.414]$} \\
Observations & 537 & 537 & 529 & 529 \\
R-squared & 0.360 & 0.162 & 0.206 & 0.254 \\
\hline
\end{tabular}

Panel B: 2SLS with continent dummies

\begin{tabular}{lcccc}
\hline Imm. rate & -0.327 & $1.179^{* * *}$ & -0.0941 & $-1.381^{* *}$ \\
& {$[0.579]$} & {$[0.304]$} & {$[0.321]$} & {$[0.646]$} \\
Trade/GDP & 0.901 & -0.207 & $-0.665^{*}$ & $1.234^{*}$ \\
& {$[0.585]$} & {$[0.297]$} & {$[0.340]$} & {$[0.655]$} \\
Observations & 537 & 537 & 529 & 529 \\
R-squared & 0.366 & 0.146 & 0.252 & 0.245 \\
\hline
\end{tabular}

Note: Units of observations are OECD countries by year. The immigration rate is the ratio of new immigrants to the total population at the beginning of the year. All specifications include year dummies. Regressions including the immigration rate in the right-hand-side also include immigration-data-source dummies. Standard errors (in brackets) are robust to heteroskedasticity.

*** $\mathrm{p}<0.01,{ }^{* *} \mathrm{p}<0.05,{ }^{*} \mathrm{p}<0.1$ 
Table 6: The Effects of Immigration and Trade. Short and wider panel.

\begin{tabular}{|c|c|c|c|c|}
\hline & $\begin{array}{c}(1) \\
\Delta \ln (\mathrm{GDP} / \mathrm{Pop})\end{array}$ & $\begin{array}{c}(2) \\
\Delta \ln (\text { Emp/Pop })\end{array}$ & $\begin{array}{c}(3) \\
\Delta \ln (\mathrm{K} / \mathrm{Emp})\end{array}$ & $\begin{array}{c}(4) \\
\Delta \ln \mathrm{TFP}\end{array}$ \\
\hline \multicolumn{5}{|l|}{ Panel A: OLS } \\
\hline Imm. rate & $\begin{array}{l}-0.458 * \\
{[0.248]}\end{array}$ & $\begin{array}{c}0.415 * * * \\
{[0.120]}\end{array}$ & $\begin{array}{c}-0.479 * * * \\
{[0.152]}\end{array}$ & $\begin{array}{c}-0.488 * * \\
{[0.229]}\end{array}$ \\
\hline Trade/GDP & $\begin{array}{c}1.361 * * * \\
{[0.273]}\end{array}$ & $\begin{array}{c}0.518 * * * \\
{[0.139]}\end{array}$ & $\begin{array}{c}-0.148 \\
{[0.190]}\end{array}$ & $\begin{array}{c}0.631 * * * \\
{[0.236]}\end{array}$ \\
\hline Observations & 255 & 248 & 246 & 246 \\
\hline R-squared & 0.387 & 0.281 & 0.133 & 0.229 \\
\hline \multicolumn{5}{|c|}{ Panel B: Two-stage least squares } \\
\hline Imm. rate & $\begin{array}{l}0.0239 \\
{[0.319]}\end{array}$ & $\begin{array}{c}0.821 * * * \\
{[0.214]}\end{array}$ & $\begin{array}{c}0.244 \\
{[0.277]}\end{array}$ & $\begin{array}{c}-0.878 * * * \\
{[0.338]}\end{array}$ \\
\hline Trade/GDP & $\begin{array}{l}0.586 * \\
{[0.352]}\end{array}$ & $\begin{array}{c}0.144 \\
{[0.201]}\end{array}$ & $\begin{array}{c}-1.126^{* * *} \\
{[0.310]}\end{array}$ & $\begin{array}{c}0.814 * * \\
{[0.359]}\end{array}$ \\
\hline Observations & 240 & 240 & 240 & 240 \\
\hline R-squared & 0.305 & 0.239 & 0.036 & 0.226 \\
\hline \multicolumn{5}{|c|}{ Panel C: 2SLS with continent dummies } \\
\hline Imm. rate & $\begin{array}{l}-0.0912 \\
{[0.447]}\end{array}$ & $\begin{array}{c}1.030 * * * \\
{[0.309]}\end{array}$ & $\begin{array}{l}-0.0639 \\
{[0.382]}\end{array}$ & $\begin{array}{c}-1.101 * * \\
{[0.454]}\end{array}$ \\
\hline Trade/GDP & $\begin{array}{c}0.679 \\
{[0.534]}\end{array}$ & $\begin{array}{c}-0.152 \\
{[0.335]}\end{array}$ & $\begin{array}{c}-0.749 \\
{[0.464]}\end{array}$ & $\begin{array}{l}1.078 * * \\
{[0.524]}\end{array}$ \\
\hline Observations & 240 & 240 & 240 & 240 \\
\hline R-squared & 0.317 & 0.19 & 0.146 & 0.228 \\
\hline
\end{tabular}

Note: Units of observations are OECD countries by year over the period 1998-2007. The immigration rate is the ratio of new immigrants to the total population at the beginning of the year. All specifications include year dummies. Regressions including the immigration rate in the right-hand-side also include immigration-data-source dummies. Standard errors (in brackets) are robust to heteroskedasticity.

${ }^{* * *} \mathrm{p}<0.01,{ }^{* *} \mathrm{p}<0.05,{ }^{*} \mathrm{p}<0.1$ 
Table 7: Effects of Immigration and Trade. Long balanced panel

\begin{tabular}{|c|c|c|c|c|}
\hline & $\begin{array}{c}(1) \\
\Delta \ln (\mathrm{GDP} / \mathrm{Pop})\end{array}$ & $\begin{array}{c}(2) \\
\Delta \ln (\text { Emp/Pop })\end{array}$ & $\begin{array}{c}(3) \\
\Delta \ln (\mathrm{K} / \mathrm{Emp})\end{array}$ & $\begin{array}{c}(4) \\
\Delta \ln \mathrm{TFP}\end{array}$ \\
\hline \multicolumn{5}{|l|}{ Panel A: OLS } \\
\hline \multirow[t]{2}{*}{ Imm. rate } & 0.370 & $0.506^{*}$ & -0.460 & 0.0160 \\
\hline & {$[0.257]$} & {$[0.275]$} & {$[0.294]$} & {$[0.307]$} \\
\hline \multirow[t]{2}{*}{ Trade/GDP } & $0.508 * *$ & $0.456 * *$ & $-0.655 * * *$ & 0.269 \\
\hline & [0.209] & {$[0.190]$} & {$[0.211]$} & {$[0.243]$} \\
\hline Observations & 440 & 440 & 440 & 440 \\
\hline R-squared & 0.348 & 0.198 & 0.180 & 0.279 \\
\hline \multicolumn{5}{|l|}{ Panel B: 2SLS } \\
\hline \multirow[t]{2}{*}{ Imm. rate } & 0.622 & $1.574 * * *$ & 0.255 & -1.036 \\
\hline & {$[0.751]$} & {$[0.547]$} & {$[0.561]$} & {$[0.886]$} \\
\hline \multirow[t]{2}{*}{ Trade/GDP } & 0.261 & -0.0988 & $-0.887 * *$ & 0.653 \\
\hline & [0.448] & {$[0.351]$} & [0.369] & {$[0.551]$} \\
\hline Observations & 440 & 440 & 440 & 440 \\
\hline R-squared & 0.345 & 0.129 & 0.156 & 0.251 \\
\hline \multicolumn{5}{|c|}{ Panel C: 2SLS with continent dummies } \\
\hline \multirow[t]{2}{*}{ Imm. rate } & 0.715 & $2.272 * * *$ & 0.572 & -1.746 \\
\hline & {$[1.415]$} & {$[0.852]$} & {$[0.741]$} & {$[1.712]$} \\
\hline \multirow[t]{2}{*}{ Trade/GDP } & 0.116 & -0.651 & -0.771 & 1.021 \\
\hline & {$[0.952]$} & {$[0.586]$} & {$[0.526]$} & {$[1.175]$} \\
\hline Observations & 440 & 440 & 440 & 440 \\
\hline R-squared & 0.344 & 0.031 & 0.205 & 0.218 \\
\hline
\end{tabular}

Note: The sample contains an almost balanced panel of 18 OECD countries over the period 1980-2007. The immigration rate is the ratio of new immigrants to the total population at the beginning of the year. Each specification includes year dummies and immigration-data-source dummies. Standard errors are heteroskedasticity-robust.

${ }^{* * *} \mathrm{p}<0.01,{ }^{* *} \mathrm{p}<0.05,{ }^{*} \mathrm{p}<0.1$ 
Table 8: Effects of Immigration and Trade. Net Immigration.

\begin{tabular}{|c|c|c|c|c|}
\hline & $\begin{array}{c}(1) \\
\Delta \ln (\text { GDP/Pop })\end{array}$ & $\begin{array}{c}(2) \\
\Delta \ln (\text { Emp/Pop })\end{array}$ & $\begin{array}{c}(3) \\
\Delta \ln (\mathrm{K} / \mathrm{Emp})\end{array}$ & $\begin{array}{c}(4) \\
\Delta \ln \mathrm{TFP}\end{array}$ \\
\hline \multicolumn{5}{|l|}{ Panel A: OLS } \\
\hline Net Imm. rate & $\begin{array}{c}0.306 \\
{[0.381]}\end{array}$ & $\begin{array}{c}1.050 * * * \\
{[0.222]}\end{array}$ & $\begin{array}{c}0.499 * \\
{[0.293]}\end{array}$ & $\begin{array}{c}-0.479 \\
{[0.303]}\end{array}$ \\
\hline Trade / GDP & $\begin{array}{c}0.967 * * * \\
{[0.256]}\end{array}$ & $\begin{array}{c}0.519 * * * \\
{[0.147]}\end{array}$ & $\begin{array}{c}-0.631 * * * \\
{[0.177]}\end{array}$ & $\begin{array}{l}0.395 * \\
{[0.237]}\end{array}$ \\
\hline $\begin{array}{l}\text { Observations } \\
\text { R-squared }\end{array}$ & $\begin{array}{c}177 \\
0.337\end{array}$ & $\begin{array}{c}175 \\
0.338\end{array}$ & $\begin{array}{c}172 \\
0.159\end{array}$ & $\begin{array}{c}172 \\
0.215\end{array}$ \\
\hline \multicolumn{5}{|c|}{$\begin{array}{l}\text { Panel B: Two-stage } \\
\text { least squares }\end{array}$} \\
\hline Net Imm. rate & $\begin{array}{c}0.617 \\
{[0.598]}\end{array}$ & $\begin{array}{c}1.558 * * * \\
{[0.417]}\end{array}$ & $\begin{array}{c}0.438 \\
{[0.513]}\end{array}$ & $\begin{array}{l}-1.086^{*} \\
{[0.628]}\end{array}$ \\
\hline Trade / GDP & $\begin{array}{l}0.504 * \\
{[0.293]}\end{array}$ & $\begin{array}{c}0.504 * * * \\
{[0.167]}\end{array}$ & $\begin{array}{c}-1.022 * * * \\
{[0.229]}\end{array}$ & $\begin{array}{c}0.337 \\
{[0.294]}\end{array}$ \\
\hline $\begin{array}{l}\text { Observations } \\
\text { R-squared }\end{array}$ & $\begin{array}{c}170 \\
0.332\end{array}$ & $\begin{array}{c}170 \\
0.328\end{array}$ & $\begin{array}{c}170 \\
0.128\end{array}$ & $\begin{array}{c}170 \\
0.209\end{array}$ \\
\hline \multicolumn{5}{|c|}{ Panel C: 2SLS with continent dummies } \\
\hline Net Imm. rate & $\begin{array}{c}0.746 \\
{[0.723]}\end{array}$ & $\begin{array}{c}1.798 * * * \\
{[0.542]}\end{array}$ & $\begin{array}{c}0.523 \\
{[0.705]}\end{array}$ & $\begin{array}{l}-1.225 \\
{[0.753]}\end{array}$ \\
\hline Trade / GDP & $\begin{array}{c}0.306 \\
{[0.391]}\end{array}$ & $\begin{array}{c}0.403 \\
{[0.253]}\end{array}$ & $\begin{array}{c}-1.110 * * * \\
{[0.343]}\end{array}$ & $\begin{array}{c}0.269 \\
{[0.394]}\end{array}$ \\
\hline Observations & 170 & 170 & 170 & 170 \\
\hline R-squared & 0.345 & 0.308 & 0.122 & 0.23 \\
\hline
\end{tabular}

Note: The sample contains all 30 OECD countries over the period 1998-2007. The immigration rate is the ratio of new immigrants to the total population at the beginning of the year. Each specification includes year dummies and immigration-data-source dummies. Standard errors are heteroskedasticity-robust.

$* * * \mathrm{p}<0.01,{ }^{* *} \mathrm{p}<0.05, * \mathrm{p}<0.1$ 
Table 9: Effects of Immigration and Trade. Long differences.

\begin{tabular}{|c|c|c|c|c|}
\hline & $\begin{array}{c}(1) \\
\Delta \ln (\mathrm{GDP} / \mathrm{Pop})\end{array}$ & $\begin{array}{c}(2) \\
\Delta \ln (\text { Emp/Pop })\end{array}$ & $\begin{array}{c}(3) \\
\Delta \ln (\mathrm{K} / \mathrm{Emp})\end{array}$ & $\begin{array}{c}(4) \\
\Delta \ln \mathrm{TFP}\end{array}$ \\
\hline \multicolumn{5}{|c|}{ Panel A: OLS } \\
\hline Imm. rate & $\begin{array}{c}-0.370 \\
{[0.323]}\end{array}$ & $\begin{array}{l}0.373^{*} \\
{[0.210]}\end{array}$ & $\begin{array}{c}-0.614 * * * \\
{[0.232]}\end{array}$ & $\begin{array}{c}-0.399 \\
{[0.280]}\end{array}$ \\
\hline Trade/GDP & $\begin{array}{c}4.618^{* * *} \\
{[1.396]}\end{array}$ & $\begin{array}{l}1.745^{* *} \\
{[0.814]}\end{array}$ & $\begin{array}{c}-1.296 \\
{[1.008]}\end{array}$ & $\begin{array}{l}2.449 * * \\
{[1.189]}\end{array}$ \\
\hline $\begin{array}{l}\text { Observations } \\
\text { R-squared }\end{array}$ & $\begin{array}{c}117 \\
0.337\end{array}$ & $\begin{array}{c}117 \\
0.292\end{array}$ & $\begin{array}{c}116 \\
0.309\end{array}$ & $\begin{array}{c}116 \\
0.150\end{array}$ \\
\hline \multicolumn{5}{|c|}{$\begin{array}{l}\text { Panel B: Two-stage least } \\
\text { squares }\end{array}$} \\
\hline Imm. rate & $\begin{array}{l}-0.256 \\
{[0.503]}\end{array}$ & $\begin{array}{c}1.112 * * * \\
{[0.408]}\end{array}$ & $\begin{array}{l}-0.0405 \\
{[0.412]}\end{array}$ & $\begin{array}{l}-1.191^{* *} \\
{[0.522]}\end{array}$ \\
\hline Trade/GDP & $\begin{array}{c}3.312 * \\
{[1.930]}\end{array}$ & $\begin{array}{l}-0.242 \\
{[1.345]}\end{array}$ & $\begin{array}{c}-3.104 * * \\
{[1.547]}\end{array}$ & $\begin{array}{l}3.852^{*} \\
{[2.181]}\end{array}$ \\
\hline $\begin{array}{l}\text { Observations } \\
\text { R-squared }\end{array}$ & $\begin{array}{c}117 \\
0.331\end{array}$ & $\begin{array}{c}117 \\
0.196\end{array}$ & $\begin{array}{c}116 \\
0.276\end{array}$ & $\begin{array}{c}116 \\
0.096\end{array}$ \\
\hline \multicolumn{5}{|c|}{ Panel C: 2SLS with continent dummies } \\
\hline Imm. rate & $\begin{array}{c}-0.402 \\
{[0.738]}\end{array}$ & $\begin{array}{l}1.264^{* *} \\
{[0.516]}\end{array}$ & $\begin{array}{l}-0.0718 \\
{[0.511]}\end{array}$ & $\begin{array}{l}-1.443^{*} \\
{[0.745]}\end{array}$ \\
\hline Trade/GDP & $\begin{array}{c}3.414 \\
{[3.221]}\end{array}$ & $\begin{array}{l}-1.012 \\
{[1.814]}\end{array}$ & $\begin{array}{l}-2.619 \\
{[2.117]}\end{array}$ & $\begin{array}{c}4.418 \\
{[3.344]}\end{array}$ \\
\hline $\begin{array}{l}\text { Observations } \\
\text { R-squared }\end{array}$ & $\begin{array}{c}117 \\
0.349\end{array}$ & $\begin{array}{c}117 \\
0.155\end{array}$ & $\begin{array}{c}116 \\
0.350\end{array}$ & $\begin{array}{c}116 \\
0.099\end{array}$ \\
\hline
\end{tabular}

Note: The units of observations are all 30 OECD countries over the period 1980-2007. All specifications include period dummies. Standard errors are robust to heteroskedasticity. Each period is the aggregate of 4 years: $1982-86,1986-90, \ldots, 2002-06$.

${ }^{* * *} \mathrm{p}<0.01,{ }^{* *} \mathrm{p}<0.05,{ }^{*} \mathrm{p}<0.1$ 


\section{Tables Appendix}

Table A1: Number of immigration sending countries recorded in the Bilateral data constructed by Ortega and Peri (2009)

\begin{tabular}{|c|c|c|c|c|}
\hline country & 1980 & 1990 & 2000 & 2007 \\
\hline Australia & 54 & 156 & 195 & 196 \\
\hline Austria & & & 160 & 17 \\
\hline Belgium & 26 & 29 & 68 & 33 \\
\hline Canada & 161 & 176 & 196 & 199 \\
\hline Czech Republic & & & 13 & 32 \\
\hline Denmark & 118 & 123 & 143 & 174 \\
\hline Finland & 83 & 7 & 71 & 203 \\
\hline France & & 11 & 201 & 203 \\
\hline Germany & 103 & 104 & 192 & 194 \\
\hline Great Britain & & 78 & 103 & 93 \\
\hline \multicolumn{5}{|l|}{ Greece $^{\mathrm{a}}$} \\
\hline Hungary & & & 33 & 201 \\
\hline Ireland $^{\mathrm{b}}$ & & & 2 & 2 \\
\hline Italy & 24 & 30 & 182 & 36 \\
\hline Japan & 12 & 12 & 10 & 202 \\
\hline Korea & & & 10 & 28 \\
\hline Luxembourg & & 9 & 201 & 203 \\
\hline Mexico & & & & 125 \\
\hline Netherlands & 17 & 14 & 198 & 160 \\
\hline New Zealand & 10 & 50 & 50 & 201 \\
\hline Norway & 100 & 149 & 200 & 202 \\
\hline Poland & & & 61 & 89 \\
\hline Portugal & & & 16 & 24 \\
\hline Slovakia & & & & 191 \\
\hline Spain & 24 & 42 & 157 & 198 \\
\hline Sweden & 134 & 149 & 165 & 193 \\
\hline Switzerland & & 12 & 34 & 32 \\
\hline Turkey & & & 200 & 200 \\
\hline USA & 182 & 192 & 211 & 181 \\
\hline
\end{tabular}

Note: the database is constructed by Merging data from the Ortega and Peri (2009), the UN (2005) and the IMD (2010) databases as described in the Text.

a: Greece has only data for 1998

b: Ireland reports immigrants from individual country only for the US and the UK. 
Table A2: Sources of the Immigration Data

\begin{tabular}{|c|c|c|c|}
\hline Sources of the Data: & $\begin{array}{l}\text { Ortega and Peri } \\
2009\end{array}$ & $\begin{array}{l}\text { United } \\
\text { Nations }\end{array}$ & $\begin{array}{l}\text { International Migration } \\
\text { Database }\end{array}$ \\
\hline country & years & years & years \\
\hline AUSTRALIA & $1983-2005$ & $1960-2004$ & $1998-2007$ \\
\hline AUSTRIA & n.a. & n.a. & $1998-2007$ \\
\hline BELGIUM & $1984-2005$ & $1960-2003$ & $1998-2007$ \\
\hline CANADA & $1980-2005$ & $1961-2004$ & $1998-2007$ \\
\hline CZECH REPUBLIC & n.a. & n.a. & $1998-2007$ \\
\hline DENMARK & $1990-2004$ & $1980-2004$ & $1998-2007$ \\
\hline FINLAND & n.a. & $1980-2004$ & $1998-2007$ \\
\hline FRANCE & $1984-2005$ & $1994-2003$ & $1998-2007$ \\
\hline GREECE & n.a. & n.a. & $1998-2007$ \\
\hline GERMANY & $1984-2005$ & $1965-2004$ & $1998-2007$ \\
\hline HUNGARY & n.a. & n.a. & $1998-2007$ \\
\hline IRELAND & n.a. & n.a. & $1998-2007$ \\
\hline ITALY & n.a. & $1980-2000$ & $1998-2007$ \\
\hline JAPAN & $1980-2005$ & n.a. & $1998-2007$ \\
\hline KOREA & n.a. & n.a. & 1998-2007 \\
\hline LUXEMBOURG & $1983-2005$ & n.a. & $1998-2007$ \\
\hline MEXICO & n.a. & n.a. & $1998-2007$ \\
\hline NETHERLANDS & $1984-2005$ & $1960-2004$ & $1998-2007$ \\
\hline NEW ZEALAND & n.a. & $1950-2004$ & $1998-2007$ \\
\hline NORWAY & $1984-2005$ & $1980-2003$ & $1998-2007$ \\
\hline POLAND & n.a. & n.a. & $1998-2007$ \\
\hline PORTUGAL & n.a. & n.a. & $1998-2007$ \\
\hline SLOVAK REPUBLIC & n.a. & n.a. & $2003-2007$ \\
\hline SPAIN & n.a. & $1980-2004$ & $1998-2007$ \\
\hline SWEDEN & $1980-2005$ & $1960-2004$ & $1998-2007$ \\
\hline SWITZERLAND & 1984-2005 & n.a. & $1998-2007$ \\
\hline TURKEY & n.a. & n.a. & $1998-2007$ \\
\hline UNITED KINGDOM & $1982-2006$ & $1964-2003$ & $1998-2001$ \\
\hline UNITED STATES & $1980-2006$ & $1946-2004$ & 1998-2007 \\
\hline
\end{tabular}


Table A3: The effects of immigration and trade openness. Sample excludes Luxembourg.

\begin{tabular}{|c|c|c|c|c|}
\hline \multicolumn{5}{|l|}{ Panel A: OLS } \\
\hline & (1) & $(2)$ & (3) & (4) \\
\hline & $\Delta \ln (\mathrm{GDP} / \mathrm{Pop})$ & $\Delta \ln ($ Emp/Pop) & $\Delta \ln (\mathrm{K} / \mathrm{Emp})$ & $\Delta \ln \mathrm{TFP}$ \\
\hline \multirow[t]{2}{*}{ Imm. rate } & 0.477 & $0.349^{*}$ & 0.343 & 0.0223 \\
\hline & {$[0.360]$} & {$[0.183]$} & {$[0.244]$} & {$[0.401]$} \\
\hline \multirow[t]{2}{*}{ Trade/GDP } & $8.187 * * *$ & $1.349^{*}$ & $-3.916 * * *$ & $7.836 * * *$ \\
\hline & {$[1.234]$} & [0.809] & {$[0.956]$} & {$[1.286]$} \\
\hline Observations & 520 & 512 & 511 & 511 \\
\hline R-squared & 0.518 & 0.234 & 0.435 & 0.395 \\
\hline \multicolumn{5}{|c|}{ Panel B: Two-stage least squares } \\
\hline \multirow[t]{2}{*}{ Imm. rate } & 0.561 & 0.577 & -0.791 & 0.322 \\
\hline & {$[0.880]$} & {$[0.678]$} & {$[0.786]$} & {$[0.855]$} \\
\hline \multirow[t]{2}{*}{ Trade/GDP } & 0.101 & 0.0504 & $-1.015 * * *$ & 0.318 \\
\hline & {$[0.384]$} & {$[0.228]$} & [0.298] & {$[0.365]$} \\
\hline Observations & 512 & 512 & 504 & 504 \\
\hline R-squared & 0.327 & 0.140 & 0.218 & 0.274 \\
\hline
\end{tabular}

Note: The units of observations are all OECD countries, excluding Luxembourg over the period 1980-2007. The immigration rate is the ratio of new immigrants to the total population at the beginning of the year. Each specification includes year fixed effects and we use the imputed trade and immigration as instruments. Standard errors are heteroskedasticityrobust.

*** $\mathrm{p}<0.01,{ }^{* *} \mathrm{p}<0.05,{ }^{*} \mathrm{p}<0.1$ 
Table A4: The Effects of immigration and trade. Excludes OECD-OECD migration.

\begin{tabular}{lcccc}
\hline Panel A: OLS & & & & \\
\hline & $(1)$ & $(2)$ & $(3)$ & $(4)$ \\
& $\Delta \ln (\mathrm{GDP} / \mathrm{Pop})$ & $\Delta \ln (\mathrm{Emp} / \mathrm{Pop})$ & $\Delta \ln (\mathrm{K} / \mathrm{Emp})$ & $\Delta \ln (\mathrm{TFP})$ \\
\hline & & & & \\
Imm. rate & -0.331 & $0.751^{* * *}$ & 0.0571 & -0.705 \\
& {$[0.462]$} & {$[0.249]$} & {$[0.363]$} & {$[0.454]$} \\
Trade/GDP & $-3.402^{*}$ & 2.128 & $-6.869^{* * *}$ & -2.778 \\
& {$[1.975]$} & {$[1.493]$} & {$[2.011]$} & {$[2.045]$} \\
& & & & \\
Observations & 521 & 512 & 512 & 512 \\
R-squared & 0.346 & 0.135 & 0.177 & 0.279 \\
\hline Panel B: Two-stage least-squares & & & \\
\hline Imm. rate & 2.143 & $7.963^{* *}$ & $-5.593^{*}$ & $-3.119^{*}$ \\
& {$[3.175]$} & {$[3.581]$} & {$[2.957]$} & {$[1.832]$} \\
Trade/GDP & $47.83^{*}$ & $52.97^{*}$ & $-40.47^{*}$ & 3.895 \\
& {$[24.45]$} & {$[28.00]$} & {$[21.69]$} & {$[13.38]$} \\
& & & & \\
Observations & 512 & 512 & 504 & 504 \\
\hline
\end{tabular}

Note: The units of observations are all OECD countries over the period 1998-2007. The immigration rate is the ratio of new immigrants to the total population at the beginning of the year. Immigration rates and trade/GDP ratios are calculated including only non-OECD countries as countries of origin of migrants or trading partners. Each specification includes year fixed effects and we use the imputed trade and immigration as instruments. Standard errors are heteroskedasticity robust.

$* * * \mathrm{p}<0.01,{ }^{* *} \mathrm{p}<0.05,{ }^{*} \mathrm{p}<0.1$ 